Article

\title{
Beyond Food Security: Challenges in Food Safety Policies and Governance along a Heterogeneous Agri-Food Chain and Its Effects on Health Measures and Sustainable Development in Mexico
}

\author{
Yesica Mayett-Moreno ${ }^{1, *}$ and Juan Manuel López Oglesby ${ }^{2}$ (1) \\ 1 Graduate School of Business, Universidad Popular Autónoma del Estado de Puebla, 72410 Puebla, Mexico \\ 2 Graduate School of Engineering, Universidad Popular Autónoma del Estado de Puebla, 72410 Puebla, \\ Mexico; juanmanuel.lopez@upaep.mx \\ * Correspondence: yesica.mayett@upaep.mx; Tel.: +52-222-229-9400 x 7527; +52-(045)-222-449-22-02
}

Received: 30 October 2018; Accepted: 11 December 2018; Published: 13 December 2018

check for updates

\begin{abstract}
This work describes the relevance of food policies and governance to reach food safety issues along a heterogeneous food chain, in the context of the Food and Agriculture Organization of the United Nations (FAO) food security definition. Using personal interviews with agents in the food chain, and secondary data from 2014-2018, this exploratory research demonstrated that: (a) Mexican food policies regarding food safety are oriented to the exports markets and/or high income producers-consumers; (b) this has split the agri-food chain in two: one serving international and/or high income consumers, and another serving domestic markets; (c) the agri-food chain that serves domestic markets experiences regulatory budget shortfalls, lacks coordination in food regulations across its agents, and brings about alternate informal markets that put peoples' health and financial stability at risk, especially those lower-income consumers. Only $0.7 \%$ of producers, $12.5 \%$ of supermarkets and $42.8 \%$ of restaurants have some type of food safety certifications. This is worsened by the way public resources have been distributed, focused, prioritized, and planned. If the differences between big, medium and small producers continue to increase, it will increase regional and individual inequality, leading to two different countries: one developed and one developing, challenging its sustainable development.
\end{abstract}

Keywords: domestic markets; small producers; retailers; informal restaurants; low-income population; federal budget; externally oriented production; out of home food; inequalities; food certifications

\section{Introduction}

\subsection{Food Security and the Importance of Food Safety along the Agri-Food Chain}

In accordance with Food and Agriculture Organization of the United Nations (FAO) [1] "food security exists when all people, at all times, have physical, social and economic access to sufficient, safe and nutritious food which meets their dietary needs and food preferences for an active and healthy life". This definition highlights food safety as an important component reaching food security, along with its economic, physical and social accessibility to all people, all times.

Food safety is nearly as important as food security, for without safe food the poorest population will continue to suffer negative health impacts that lead to loss of personal income, absences from school, and an inability to work due to illness. Unsafe food creates a vicious cycle of disease and malnutrition, impeding socioeconomic development by straining healthcare systems, harming national economies, tourism and trade. Many communicable and non-communicable diseases are caused by 
contaminated food and water. Food security can be jeopardized by pests, plant, animal health diseases and/or contamination in any part of the food chain $[2,3]$.

The agriculture sector plays a significant role in meeting food safety requirements along all supply chain actors, ensuring that farm products remain fresh, safe and nutritious [4]. Nevertheless, this effectiveness relies on the adoption of effective public policies and governance. This would define what type food is going to be produced (according economic, socio-cultural and dietary needs), in what amounts and volumes (to give access to all people all the time), with enough quality (nutritious and safe). At the same time, these policies should coordinate and give support, resources, infrastructure, and supervision to all agents in the food chain in order to reach the goals for the whole system (Figure 1).

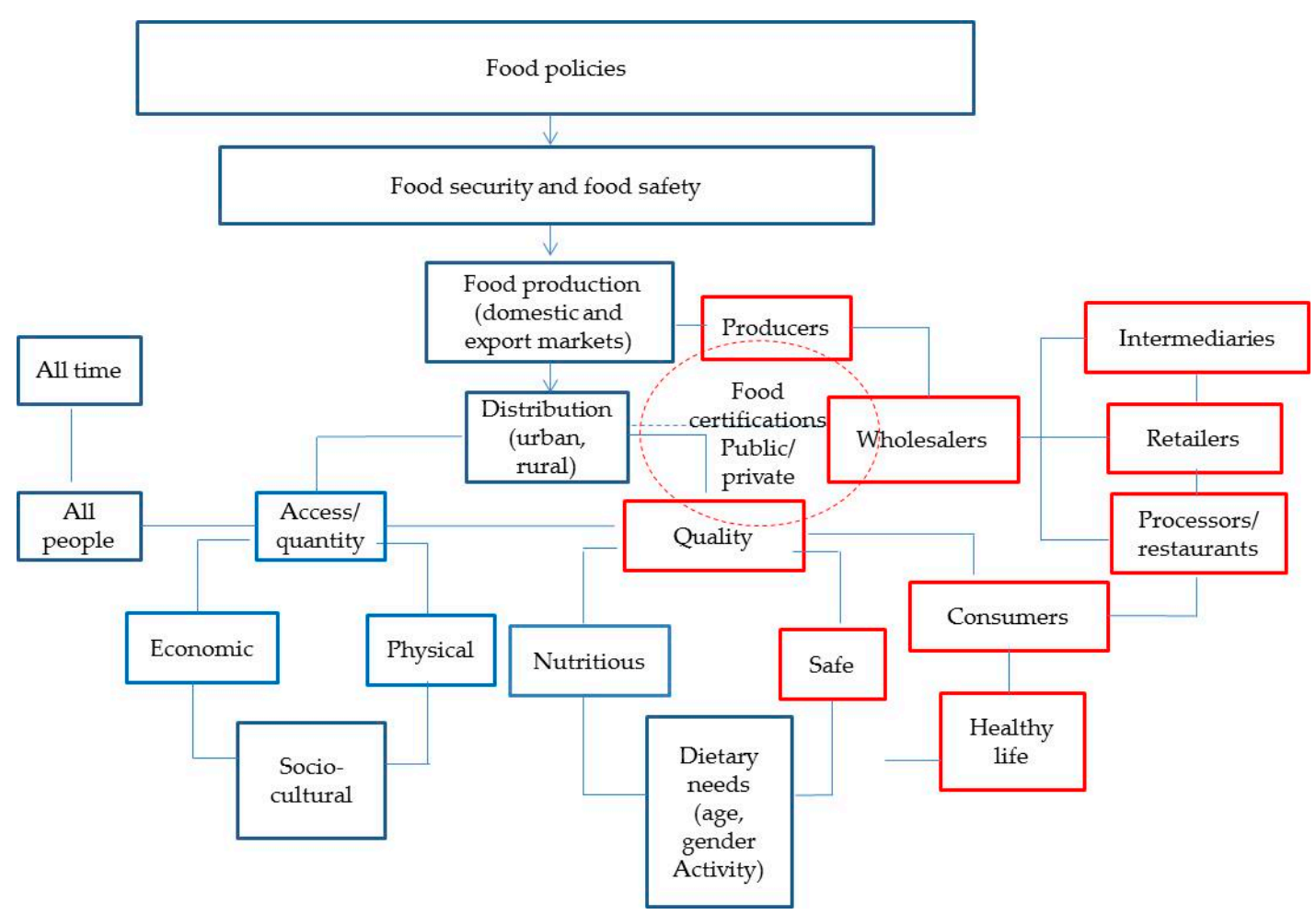

Figure 1. The importance of food policies to reach food security and safety, and the relevance of the agri-food chain as a means to attend a healthy life in all population.

It is important to understand the relationship between safe food, the importance of food certification along all agri-food chain actors, and their combined impact on health and well-being life. These actions have economic consequences in the well-being of most vulnerable population that would impact the food security measures and a sustainable development.

The World Health Organization (WHO) and the Pan American Health Organization (PAHO) have estimated that unsafe food causes one tenth of worldwide illnesses, leading to the death of about 420,000 adults and 125,000 children annually $[2,5,6]$. The WHO has found that foodborne illnesses and deaths particularly affect low and medium-income countries where the access to safe food and water by their poorest citizens remains a great challenge.

Food certifications provide the basis for food control, and supervision along the food chain. The exposure to risk is becoming higher due to fast transport, as well as national and global trade, which increase the chances for widespread transfer of contaminants. Public concern and efforts regarding food safety have always been a public health issue, derived from food-borne outbreaks of illness. Perhaps international food commerce has led to a more widespread increase in awareness, as food is the second most traded group of products globally [3]. 


\subsection{Socioeconomic Characteristics of Mexico}

\subsubsection{Food Security Challenges in Mexico}

Mexico, a country with 112.3 million people, unfortunately still has $47.5 \%$ of its population in poverty (36.6\% of them are in moderate poverty and $9.5 \%$ in extreme poverty). It has been calculated that $40.9 \%$ of people from the lowest social level have scarcity of food access [7-9]. The majority of food vulnerability is now concentrated in rural areas (36.5\%) compared to $22.9 \%$ in urban zones [8,9]. The Mexican Government implemented different aid programs since the 1940s to increase food security [8-11], and various federal agencies (the Ministry of Agriculture, Cattle, Fisheries, Rural Development and Feeding Affairs, SAGARPA; the Ministry of Rural Affairs, SDR; the Rural and Sustainable Development Law, LDRS; as well as the Ministry of Social Development, Sedesol), have coordinated these efforts for supporting the income lost "by means of cash transfers, aid in kind, supply networks and social pensions" [12]. Nevertheless, they experienced administrative horizontal and vertical coordination challenges (scarce communication, incomplete of insufficient data-bases, and target populations being marked for more than one agency or intervention), between interinstitutional authorities (ministries and governmental hierarchies). All of these factors resulted in not only lost financial resources, but lost time, reducing overall effectiveness $[1,2,7,13]$.

\subsubsection{Digestive Illness, Food Safety Concerns and Its Relation with Poverty in Mexico}

In 2012-2013, there were reported 10.9 million cases of diarrhea in Mexican children under five, along with the deaths of 944 children under the age of 14 caused by intestinal infections [14]. These infections are considered to be the fifth leading cause of death in that age group [15]. Amoebas, salmonellosis and intestinal infectious diseases caused 3536 deaths in 2013, and are considered the 20th main cause of morbidity in the Mexican population. From 1998 to 2013 deaths by gastrointestinal diseases increased $63.1 \%$ while the population increased only $15.2 \%$ in the same period [16].

For the State of Chiapas, with a population of 5.2 million people and considered one of the poorest and with more indigenous population, Díaz-Cayeros et al. [16] calculated that people experienced 25.9 years of life lost due gastrointestinal diseases, higher than 24.4 years of life lost due to cancer and 21.8 years lost due to diabetes. By contrast, in Mexico City, the capital of the country and the largest urban area with 8.9 million people, that loss of life was $21,18.3$, and 18 years, for each illness, respectively [16,17]. It should be a government's priority to ensure consumers' health through proper legislation and enforcement of rules (governance), especially in the poorest, rural and indigenous areas. This includes protecting food from chemical, physical and biological contamination, considering their impact on the economic, environmental and social outcomes. Food safety is, therefore, a prerequisite for food security, and the concepts are inextricable linked $[3,18,19]$.

Another example is the State of Puebla (with a population of 6.1 million), where approximately $40 \%$ of the nation's vegetables are produced. Within this state, the aggregate agriculture sector's share of the state's economy was the second largest (3.6\%) just behind real estate (3.7\%), and larger than the aggregate agriculture sector at the national level (3.1\%) [20]. The value of Puebla's food production ranks sixth among Mexico's 32 states [20-22]. Yet at the same time in 2014, Puebla State's total poverty was of 3.9 million $(64.5 \%)$ and is considered the 4 th State with the poorest people, and the 5 th with people in extreme poverty in Mexico. Almost a million, experience extreme poverty $(16.2 \%)$, more than half of its population is food insecure, poorly educated, has limited resources and limited income [21,22]. In the case of Puebla, the Commission for Vegetable Sanitation (CESAVEP) budget, was only 0.05 million USD in 2017 [23-26]. Data showed that CESAVEP had only provided services to 35 of the 217 municipalities (16.1\%) in 2017 [23]. In general, the total number of Rural Economic Units (REUs) certified is extremely low, challenging food safety efforts in the state, considering that $40 \%$ of vegetables from Puebla are distributed all over the country (a REU is any place where a farmer or groups of farmers would produce and sold agricultural products in a given year) [7]. 
At the international level, Mexico has been the largest agri-food importer in Latin America [8]; and still depends on food imports of nearly $40 \%$ of all basic foods, generating challenges to its food security [27]. A troubling contradiction exists: Mexico is the 12th food producer worldwide and third in Latin America. Its agricultural sector (food, cattle and fisheries) experienced a surplus of 3175 million USD and agri-food exports reached 105,604 million USD [28,29]. Mexico has made great strides in building an internationally competitive agricultural industry. It has been in the top 15 global producers of lemon juice; avocado, agave, lemons and limes, as well as frozen, preserved and pickled vegetables. The former scenario tells us that somehow Mexican efforts regarding food security have been externally oriented. The same have been happening with safety concerns: they have been mainly centered in export and international markets, as we can see in the following section.

\subsubsection{Food Safety and Food Certification Achievements and Opportunities}

Regarding food safety, similar situations arise: Mexico is one of the five countries worldwide to meet all export food certifications (along with New Zealand, Switzerland, United States and Portugal). Such achievement has made it possible to export 18 products (nine vegetables and nine animal), to 160 countries [28]. Nevertheless, food standards are not mandatory across all domestic markets, so not all the agents along the food chain follow them. These achievements are reached mainly by most big producers, who are certified, as a requirement to participate in export activities. The conflict between certification for the international market and the lack of certification for a large part of the domestic market could be explained due to the heterogeneity of the production sector.

Food safety standards are not new to some Mexican producers and other agents along the agri-food chain. Indeed, there has been gradual progress in embracing certification since the 1960s, mainly in response to demands from foreign food export activities. These efforts were enhanced in part due to the North American Free Trade Agreement (NAFTA) signed in 1992. To date Mexican certification programs have been updated and comply with most international standards; nevertheless, food safety standards are not required across all domestic food chain markets, and are especially scarce or inexistent in those serving lower-income consumers. Some authors emphasize the need to re-focus on health certifications, and the adoption of food safety standards for domestic consumers, no matter their income or social level [30,31].

The main problem is that the national/regional and local food supply chain is fragmented and scarce in food regulations and inspectors, which leads to unsafety food being sold in the domestic market and for the most vulnerable consumers. Additionally, there is a lack of accurate information and transparency about the most common food illnesses that hinder accurate calculations of the food illness costs (direct and indirect) associated with medical treatment and its effects on well-being and productivity. This situation has set back the design and adoption of public policies to solve and prevent these issues.

\subsubsection{Food Certifications}

Several certifications have been adopted from international agreements, such as the Codex Alimentarius (a collection of internationally adopted food standards aim at protecting consumers' health and ensuring fair practices in food, to facilitate international trade [32]), and recently the Food Safety Modernization Act (FSMA) [33].

These certification programs are administered by three federal agencies such as SAGARPA, the Ministry of Economy (SE) [34] and the Ministry of Health (SS), to attend food safety along the agri-food chain (Figure 2). Derived from these, there is the National Service for Disease Control, Safety and Agri-food Quality (SENASICA) in charge of inspections regarding epidemiologically issues, pests, pesticides and drugs, animal and plant health, laboratories, food imports and exports, and biosafety for genetically modified organisms (GMOs). In each state there also exist local disease, safety and quality services (for example in Puebla, there exists the CESAVEP) [28]. The Ministry of Health (SS) and the Federal Commission against Diseases Risks (COFEPRIS) evaluates and gives permits in agro-chemicals 
and food products, advertising, and performs inspections on processed food and at the point of purchase [35].

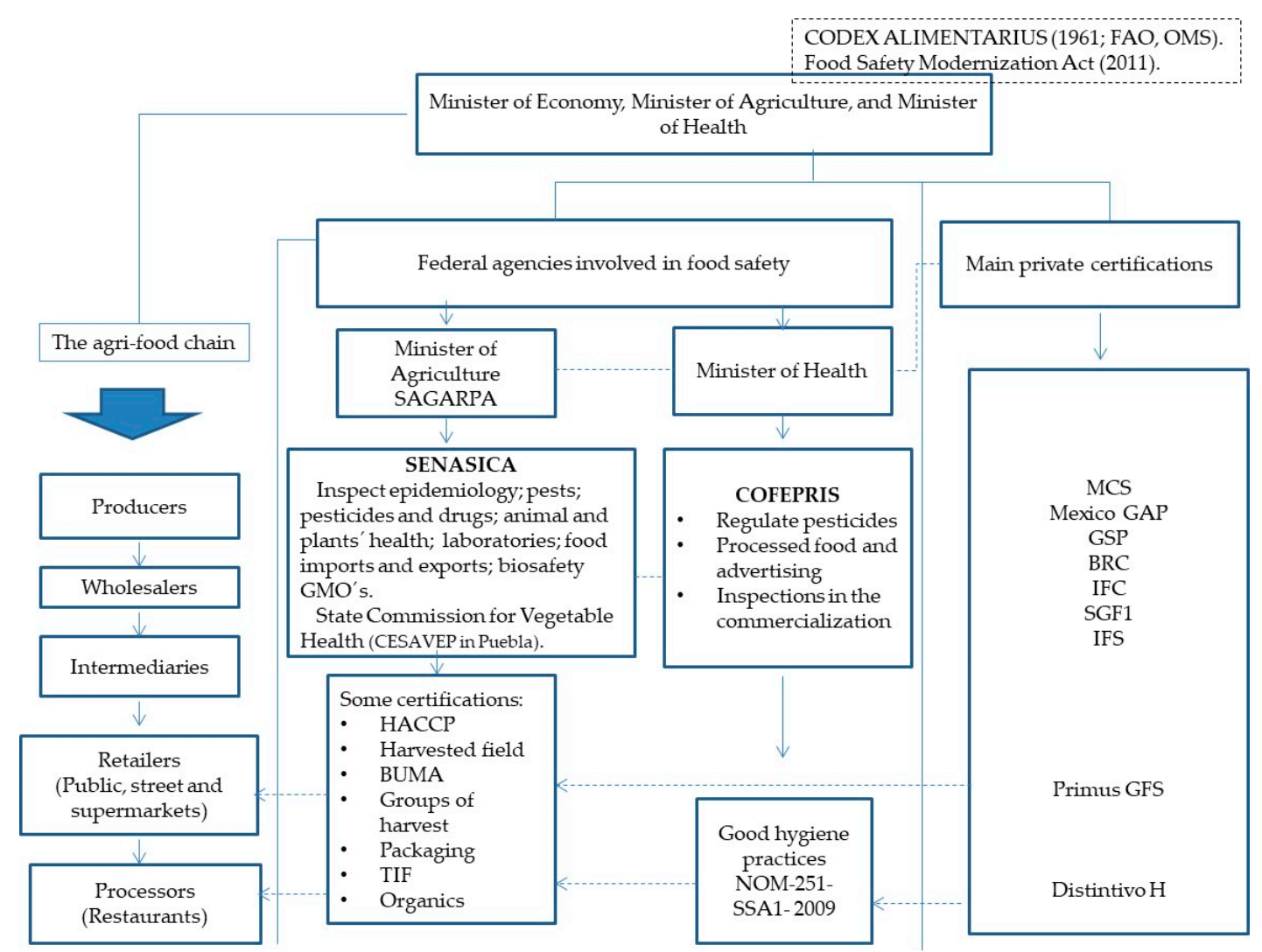

Figure 2. Main federal agencies and some private certifications involved in food safety in the Mexican agri-food chain.

To date, SENASICA issues the following official certifications that can be adopted along all agents in the agri-food chain: (a) Hazard Analysis Critical Control Point (HACCP) to reach the FSMA; (b) Best Use and Handling of Agrochemicals (BUMA); (c) Groups of teams of peasants; (d) Packaging certifications; (e) Federal Inspection Type (TIF), to meat producers and processors; and (f) Organic Certifications [28]. Additionally, Good Hygiene Practices (GHP) and the NOM NOM-251-SSA1-2009 0, both issued by COFEPRIS, are especially designed to enhance food safety in processors (restaurants).

Despite those certification efforts nationwide, the National Evaluation Council of the Social Development Policy (CONEVAL), who is in charge of evaluating the performance of federal programs, reported that even when the health and food safety information regard the primary production was published, it was often inaccurate and lacking in quantitative measurements. The food safety concerns in SENASICA are mainly in pest eradication and controlling plant pathogens [36], and do not consider supervision along the food domestic chain, the retailers (traditional markets, low-profile supermarkets, street markets) or points of purchase (street food, street markets, informal restaurants).

Simultaneously, several private certifications (such as Mexico Calidad Suprema, MCS, Mexico Good Agricultural Practices, GAP), could be adopted by all agents in the food chain at different costs [37]. At the retail level Primus GFS is required by some supermarkets, as well as "Distintivo H" for restaurants $[38,39]$. 
1.2.5. The Heterogeneity in the Mexican Agricultural Sector and Its Challenges in Achieving Food Safety

The heterogeneity at the farm level (REUs) can be understood considering Mexican history and economic models. Even when the economic development model before 1940 was mainly agriculturally oriented, from 1940 to 1965 Mexico adopted a closed economy model (the Import Substitution Model, ISM). In those decades, the agriculture production sector was supported with technical, infrastructure, and seed aid (known as the "the Green Revolution") to increase its productivity $[22,27,40]$. The ISM model called for the increase in the agricultural sector to help finance the industrialization process adopted in 1940. All incomes obtained in the agriculture were devoted to urbanization purposes and industrial development, causing the former to gradually be de-capitalized. Under the ISM model, the government minimized imports and focused on domestically-produced industrial products for consumption. Investment was directed to industrial infrastructure which accelerated the migration to urban areas, reducing the number of people who could work in agricultural production [22,41]. The extended ISM model resulted in a bi-modal food production structure whereby a large number of small producers had low productivity and a few, highly productive farmers, produce food for export or high-income domestic markets. When oil prices fell in 1979, public expenditures on food subsidies were cut. By 1982, a severe economic crisis occurred and the government seized control of all banks and private enterprises in order to avoid capital migration. Throughout the 1980s, subsidies to the domestic agriculture sector were restricted. Gradually from 1982 to 1988, the "Open Economy" Model was adopted as NAFTA was signed in the early 90s. Because of five decades of federal policies downplaying agriculture, this sector experienced a gradual decline. In order to compete with imported food products, the agricultural sector turned its production to fruits and vegetables that were more profitable and reduced the local food production of basic staples such as corn and beans. These choices led to many of the rural areas becoming the poorest nationally $[18,19]$ and the majority of food vulnerability is now concentrated there (36.5\%) compared to $22.9 \%$ in urban zones [30]. This led to the current structures of the 5.3 million REUs arising from differences in the access to markets, hectares (ha) owned, assets value, access to credit, and annual cash income (Table 1) $[7,21,41]$.

For Category E1 (subsistence producers/family farmers) and Category E2 (subsistence with minimal local market interaction), despite comprising the largest sector (73.0\% of all REUs); their productivity inputs are among the lowest, access to credit is scarce, and the few owned hectares are small (3.5-8.8 ha, respectively), and their total asset value is low. This condition affects the farms families' food availability and safety.

Categories E3-E4 account for $18.2 \%$ of REUs. They sell in domestic markets, but productivity of their inputs is low and access to credit is still minimal. Even though they have more ha under cultivation, their total asset value is still low, thus making investment in infrastructure (refrigeration, warehouses, transport, and processing technology) unaffordable. These producers typically sell immediately upon harvest and usually at lower prices. As domestic and local markets are distant and not well connected, their crop losses are in the range of $15-35 \%[18,19]$, negatively affecting their incomes.

Category E5 accounts for $8.4 \%$ of total REUs. They have access to more sophisticated domestic markets, usually in urban areas. Of these E5 REUs $44.5 \%$ have access to credit and thus infrastructure investment opportunities. They utilize the most productive land in the country. They are located in the West, Northwest, and Central regions, some of the most productive areas in the country.

Category E6 export producers are distributed primarily in the same regions as E5 REUs. However, these E6 producers account for only $0.3 \%$ of all REUs. They have extensive know-how, technology and infrastructure, can produce foods demanded by international markets and can add value to the raw foods produced. Half of these producers have access to credit, have high-value assets, and thus can afford to comply with food safety standards. 
Table 1. Classifying farm Rural Economic Units (REUs) by access to market, size, access to credit and cash income in Mexico (2013-2014).

\begin{tabular}{|c|c|c|c|c|c|c|}
\hline REUs Type & $\begin{array}{l}\text { Contact with Market }{ }^{a} / \text { Destination of } \\
\text { the Production }\end{array}$ & $\begin{array}{c}\% \text { REUs } \\
(n=5.32 \text { million })\end{array}$ & Cultivated Hectares & $\begin{array}{c}\text { Assets Value } \\
\text { (Thousand USD) }\end{array}$ & $\begin{array}{c}\text { Access to Credit Per } \\
\text { REU (\%) }\end{array}$ & $\begin{array}{c}\text { Estimated Cash } \\
\text { Income (Annual) USD }\end{array}$ \\
\hline E1 Subsistence family farms & None/self-consumption & 22.4 & 3.5 & 0.23 & No access & $<869.1$ \\
\hline $\begin{array}{l}\text { E2 Subsistence family farms } \\
\text { with access to markets }\end{array}$ & $\begin{array}{l}\text { Limited/self-consumption and } \\
\text { national market }\end{array}$ & 50.6 & 8.8 & 2.35 & 2.7 & 869.1 \\
\hline E3 Transition & Occasional/national market & 8.3 & 32.3 & 8.23 & 7.8 & 3989.9 \\
\hline E4 Weak profit & $95 \%$ a /national market & 9.9 & 37.5 & 14.11 & 13.1 & 7771.4 \\
\hline E5 Young entrepreneurs & $100 \% \mathrm{a} /$ national market & 8.4 & 141.4 & 44.11 & 44.5 & $28,773.7$ \\
\hline E6 Dynamic entrepreneurs & $100 \%$ a $/$ national \& international market & 0.3 & 297.6 & 285.11 & 50.5 & $>28,773.7$ \\
\hline Total & & 100 & 521.1 & 364.95 & & \\
\hline
\end{tabular}

Source: calculated from the Official Journal of the Federal Government of Mexico [7,21]. These are official data and due to rounding and exchange rates do not sum to exactly $100 \%$.

Exchange rate: $\$ 1$ USD $=\$ 19.0$ Mexican pesos at the time this article's preparation. 


\subsubsection{Consumer' Socioeconomic Profiles, Their Access to Food Security and Safety}

To guarantee access to food, consumers must have enough income. Some studies recognize that most of the problem of food insecurity is income concentration, and the loss in purchasing power, not just the food supply [8,9,42]. In Mexico, most of the country's income is concentrated among very few people. In 2010, $70.0 \%$ of Mexicans held only $38.0 \%$ of the national wealth; meanwhile the upper $10 \%$ owned $33.8 \%$ of the wealth [43]. Derived from this, each type of consumer spends their budget for food in different ways. Mexico as a medium income country, possesses an income elasticity coefficient for food of 0.646 and the portion spent on vegetables was 0.084 . In comparison, in the USA these elasticities were 0.346 and 0.061 , respectively [44]. When there is less purchasing power and food remains a necessity item, people with lower incomes increase their relative expenditure on that item [45]. This is exactly what is happening in Mexico: food remains the largest expense category (35.2\%) in the budget for most Mexicans [43]. But the lowest income population (about 14.4 million households, equivalent to approximately 57.6 million people), devotes $34.1 \%$ of their household budget to food, compared to $32.4 \%$ and $33.5 \%$ for medium and high-income levels, respectively [43]. At the same time, these disparities in purchasing power and budget, tend to make lower-income people more price sensitive, pushing them to buy cheaper and, therefore, primarily uncertified food (fresh or processed), with little concern for its safety or nutritional value. This is a powerful reason to increase food safety across all sectors.

Access to safe food. Another reason to invest in safe food is its nutritious component, and the need to increase fresh food intake due the over-weight and obesity challenges faced in Mexico. In an Organisation for Economic Co-operation and Development (OECD) report, Mexico was the top country with diabetes prevalence (type I or II), as well as obese and overweight adults (20-79 years old) [46]. This problem particularly affects low income people as they have immediate physical access to "cheaper" uncertified processed food and/or junk food, intense advertising in mass media, higher relative prices of safe, nutritious fruits and vegetables, and at the same time their purchasing power has been diminished. In this sense, healthy food lifestyles such as fruit and vegetables intake are strategic. In the same report, Mexico's daily fruit and vegetables eating in its population aged 15 years and over was only $43.1 \%$ and $57.5 \%$ of the recommended daily intake, respectively, while in Australia these values were $95.0 \%$ and $99.0 \%$, for each item. This increases the risk of illness, and the urgency to take actions in fresh food certification efforts at affordable prices. Obesity and diabetes as well as other digestive illnesses (such as cancer), generated 2210 million USD of direct costs (amount close to 13.0\% of the budget for health in 2008), and 1315.8 million USD of indirect costs [47]. Some studies calculated the costs of foodborne illness in the US between $\$ 14.1-\$ 77.7$ billion USD yearly [48]. Future research should estimate the respective Mexican cost, as well as the social, economic and health implications.

Challenges in the access to food safety in urban areas. Lifestyles, and less time for food preparation have led to an increase in out-of-home food/food to-go. In 1984 Mexicans spent $10.4 \%$ of their incomes on food-out-of home; they almost doubled this amount to $21.9 \%$ in 2016. Differences arise by income level: despite the lowest income level spending only $18.3 \%$ of their income in out-of-home food; they represent 4.4 million households (approximately 17.7 million people) which eat out-of-home (compared with 3.9 million people of the highest income levels). Those consumers with the lowest income prefer small and cheap restaurants (44.5\%), cheap tacos $(52.0 \%)$, and mobile/street food small sellers $(60.8 \%)$, [49]. Unfortunately, at the end of the food chain, many street vendors process food without following any safety protocols or supervision and control from the authorities. Moreover, many consumers do not discern among pathogens and the associated risks, and public health officials hardly communicate about or recall dangerous products or publicize specific hazards, so consumers routinely underestimate risks [50]. There is food that achieves all certifications and quality standards, as is the case of organic certified foods. Nevertheless, due the high costs to produce them, it is generally too expensive to be bought by the lower- or some medium-income consumers. This food is mainly exported or sold to high-income domestic consumers. At the same time, its economic benefits and 
impacts in the agri-food chain are limited to those producers, wholesalers, retailers and processors who can afford the certification costs.

One way or another, if only some of the variables of food security definition are attended, or some type of food is produced, we will experience effects in the agri-food chain and in the outputs for the whole society (Table 2).

The purpose of this research was to demonstrate that: (a) Mexican food policies and governance regarding food safety issues are oriented to export markets and/or in high income producers- and consumers; (b) how this situation has split the agri-food chain in two: one that serves international or high-income consumers, and another that attends domestic markets; (c) the agri-food chain that attends domestic markets experiences shortfalls in the federal budget expenditures devoted to food safety issues; (d) there is a lack of coordination in food regulations (transparency, laws, training, supervision, infrastructure), across domestic agri-food chain agents, bringing about alternate informal markets that put peoples' health at risk, especially lower income consumers, increasing illness and poverty, challenging food security.

\section{Materials and Methods}

This research is exploratory based on (a) secondary information; and (b) personal interviews with nine people knowledgeable about the subject [51]. The secondary data was gathered from national and international official databases. Due scarce data and/or contradictions in databases, we gathered official reports from different years (2014-2018). To complement the available secondary information, we designed a low-structure questionnaire of one to six items according the different actors interviewed in the agri-food chain. To administer the interviews, we combined three primary communication methods: personal, telephone and e-mail interviews. Those interviews were conducted from January to November 2018. The people interviewed were selected by convenience: an individual in the main office in the wholesale market and a front office worker for traditional markets, both in Mexico City; the SENASICA coordinator in Mexico City; the licensing coordinator for the Ministry of Health and a trainer from the same Ministry, both in the City of Puebla; two private auditors, one in Puebla and one in Mexico City; the director of the Agronomy School of Agronomy at a private university; and former employee of SDR and SAGARPA in the City of Puebla (Table 3). 
Table 2. Possible scenarios when only some variables are reached in the food security goals, and their impacts in the agri-food chain and society.

\begin{tabular}{|c|c|c|c|c|c|c|c|c|c|c|c|}
\hline & \multirow[t]{2}{*}{ FAO's Criteria } & \multirow[t]{2}{*}{ All People } & \multirow[t]{2}{*}{ All Time } & \multicolumn{3}{|c|}{ Access Sufficient (Quantity) } & \multicolumn{3}{|c|}{ Quality } & \multirow[t]{2}{*}{$\begin{array}{l}\text { Healthy } \\
\text { Life }\end{array}$} & \multirow[t]{2}{*}{ Output in Society } \\
\hline & & & & Physical & $\begin{array}{c}\text { Social } \\
\text { (Culture) }\end{array}$ & Economic & Safe & Nutritious & $\begin{array}{l}\text { Dietary } \\
\text { Needs }\end{array}$ & & \\
\hline \multicolumn{12}{|l|}{$\begin{array}{l}\text { Different } \\
\text { scenarios }\end{array}$} \\
\hline $\begin{array}{l}\text { Street food and } \\
\text { uncertified food }\end{array}$ & & Yes & Yes & Yes & Yes & Yes & No & Some & Some & No & $\begin{array}{l}\text { Food illnesses in all agents along the food chain } \\
\text { (infectious, bacteria); loss of income; poverty. }\end{array}$ \\
\hline Junk food & & Yes & Yes & Yes & No & Yes & Yes & No & No & No & $\begin{array}{l}\text { Food illnesses (overweight; obesity, diabetes, } \\
\text { cancer); loss of income; poverty. }\end{array}$ \\
\hline Organic food & & No & No & No & Some & No & Yes & Yes & No & Yes & $\begin{array}{l}\text { Feasible to produce only by } 8.7 \% \text { of all REU's. } \\
\text { Export oriented. } \\
\text { Economically feasible for only } 7.2 \% \text { of } \\
\text { consumers. }\end{array}$ \\
\hline
\end{tabular}

Table 3. Methods used to gather primary information from people knowledgeable about certification processes and requirements in this research (2018).

\begin{tabular}{|c|c|c|c|c|}
\hline $\begin{array}{l}\text { Activity through the } \\
\text { Agri-Food Chain } \\
(n=7)\end{array}$ & $\begin{array}{l}\text { Region } \\
(n=2)\end{array}$ & $\begin{array}{c}\text { Number of Interviews } \\
\text { Gathered } \\
(n=8)\end{array}$ & $\begin{array}{c}\text { Primary Communication } \\
\text { Method (Interviews) } \\
(n=3)\end{array}$ & Questions Asked \\
\hline Wholesaler main office & Mexico City and Puebla City & 2 & Telephone & Are wholesalers certified in any type of standards? \\
\hline $\begin{array}{l}\text { Traditional Markets main office } \\
\text { front desk }\end{array}$ & Mexico City & 1 & Telephone & $\begin{array}{l}\text { Are public markets and street markets certified in any type of } \\
\text { standards? }\end{array}$ \\
\hline $\begin{array}{l}\text { SENASICA } \\
\text { coordinator }\end{array}$ & Mexico City & 1 & Personal and e-mail & $\begin{array}{l}\text { 1. Which are the main federal agencies in charge of food } \\
\text { certifications? } \\
\text { 2. Which are private and which are federal? } \\
\text { 3. How does SENASICA help certify all producers? }\end{array}$ \\
\hline $\begin{array}{l}\text { Ministry of Health and License } \\
\text { Office }\end{array}$ & Puebla City & 1 & Personal & $\begin{array}{l}\text { 1. How many restaurants are certified? } \\
\text { 2. How often do restaurants have to renew their food } \\
\text { service' license? } \\
\text { 3. How many restaurants attended the NOM251-SSA1-2009 } \\
\text { lecture? } \\
\text { 4. Why does not the Ministry of Health ask informal restaurants } \\
\text { and street vendors to attend the NOM's standard? }\end{array}$ \\
\hline Ministry of Health trainer & Puebla City & 1 & Personal & $\begin{array}{l}\text { Why the Ministry of Health does not ask informal restaurants } \\
\text { and street vendors to adopt that NOM's lecture? }\end{array}$ \\
\hline
\end{tabular}


Table 3. Cont

\begin{tabular}{|c|c|c|c|c|}
\hline $\begin{array}{l}\text { Activity through the } \\
\text { Agri-Food Chain } \\
(n=7)\end{array}$ & $\begin{array}{l}\text { Region } \\
(n=2)\end{array}$ & $\begin{array}{c}\text { Number of Interviews } \\
\text { Gathered } \\
(n=8)\end{array}$ & $\begin{array}{c}\text { Primary Communication } \\
\text { Method (Interviews) } \\
(n=3)\end{array}$ & Questions Asked \\
\hline Private third-party auditor (IL) & Puebla City & 1 & Personal and telephone & $\begin{array}{l}\text { 1. What type of certifications or support do you offer? } \\
\text { 2. How much do those certification cost? } \\
\text { 3. What are the requirements? } \\
\text { 4. If there is a special amount of federal budget for agriculture } \\
\text { education, small producers' support, marketing strategies, } \\
\text { productivity, competitiveness subsectors, how is this support } \\
\text { linked with those in food safety food and SENASICA? } \\
\text { 5. What category of producers are those reported by } \\
\text { SENASICA as having certifications in the 2018 database? } \\
\text { 6. What happens regard food standards in wholesalers, public } \\
\text { and street markets? }\end{array}$ \\
\hline Private third-party auditor (GL) & Mexico City & 1 & Personal and e-mail & $\begin{array}{l}\text { 1. What type of certifications do they recommend to be adopted } \\
\text { to sell fresh fruits and vegetables food in supermarkets? } \\
\text { 2. How much do those certification cost? } \\
\text { 3. What are the requirements? } \\
\text { 4. How long does the license last? }\end{array}$ \\
\hline $\begin{array}{l}\text { Director of the Agronomy } \\
\text { School at a private University }\end{array}$ & Puebla City & 1 & Personal & $\begin{array}{l}\text { 1. Which are the main federal agencies in charge of } \\
\text { food certifications? } \\
\text { 2. Which ones are private and which are federal? } \\
\text { 3. Which agents from the agri-food chain do you think } \\
\text { are certified? }\end{array}$ \\
\hline
\end{tabular}




\subsection{Number of Food Certifications That Each Agent Has along the Agri-Food Chain}

To analyze the number of food certifications that each agent has along the agri-food chain we first estimate the total numbers of each player using a basic supply chain network. We then compared our estimates with those reported in official databases or through our interviews and estimate the relative certification for each actor [17] (Figure 3).

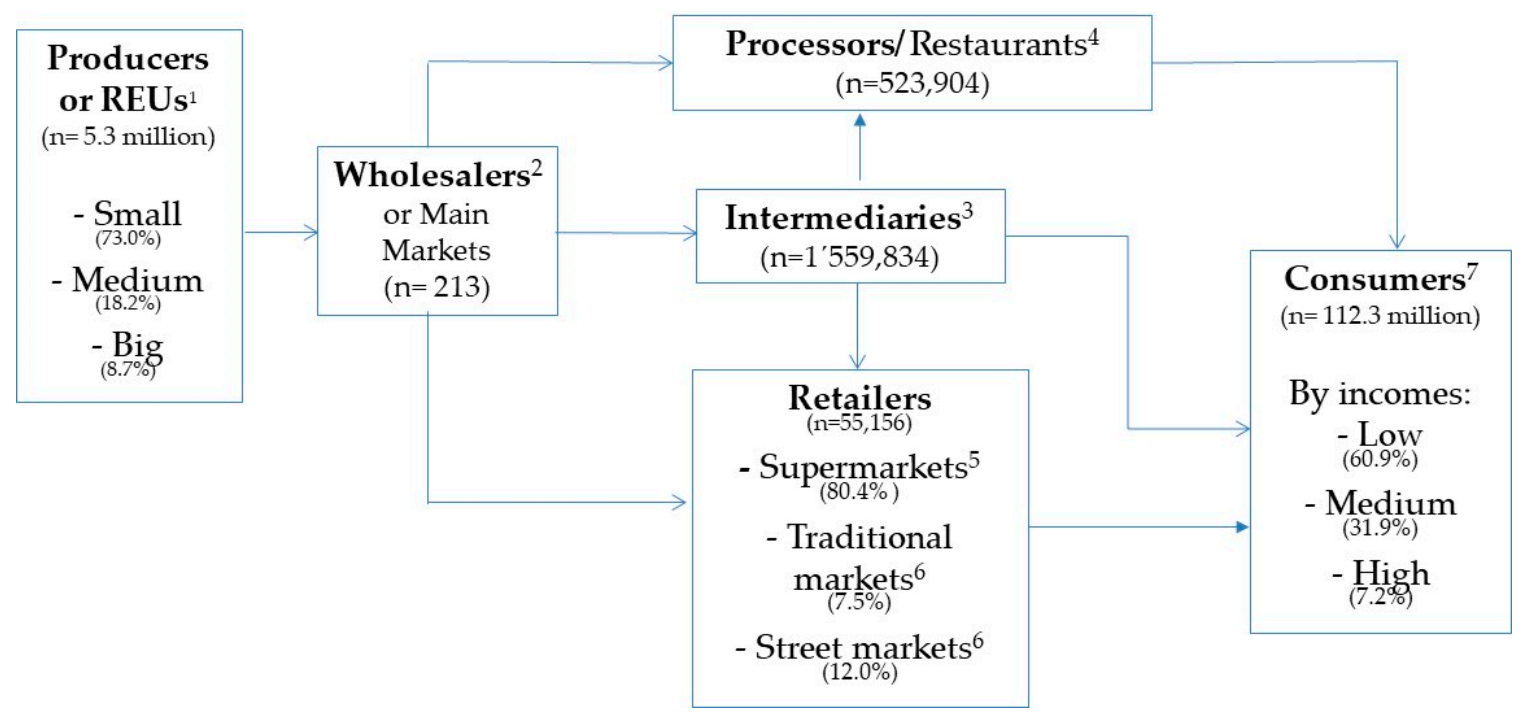

Figure 3. Quantification of the different actors in the basic supply chain network in Mexico, used in this research (frequencies and percentages where indicated). Source: ${ }^{1}$ OJFM 2014 [7]; ${ }^{2}$ Main Wholesale Center Mexico City [52,53]; ${ }^{3}$ INEGI-DENUE [54]; ${ }^{4}$ INEGI [55], 5,6 SEDECO, 2015 [56], ANTAD, 2018 [56,57]; ${ }^{7}$ INEGI, 2010 [58].

For this research we merged REUs into three categories: Low = E1 Subsistence family farms and E2 Subsistence family farms with some access to the market (73.0\%); Medium = E3 Transition and E4 Weak profits (18.0\%); Big = E5 Young entrepreneurs and E6 Dynamic entrepreneurs (8.7\%) [7,21].

To calculate the number of certified REUSs, we took a 2018 database with 14,431 food certifications published by SENASICA and the Agri-food and Fisheries Information Service (SIAP) both part of SAGARPA [59,60]. That report included the 32 Mexican States, 145 fresh fruits and vegetables, certified hectares as well as 5 types of certifications (open land; BUMA and SRRC fields, groups of harvest farmers, and packaging). Using crosstabs, median, mode and averages in SPSS ${ }^{\circledR}$ Ver 22, we obtained frequencies and percentages, of the main products that obtained a certification according to each product, State, hectares and certification type. For Organic food certifications we took the information from SAGARPA's 2017 report [28].

\subsection{Wholesalers}

According to official information from the main wholesale center webpage [52-54], there exist nearly 213 wholesalers registered in the country. Given the scarcity of information regarding which ones were certified, we confirmed directly with the main office in the wholesale market in Mexico City.

\subsection{Intermediaries}

Before being bought by retailers and processors, fresh food moves through roughly 1,559,834 officially-registered intermediaries [54], but we did not find evidence of which ones were certified, nor a person or association that would give us that information. 


\subsection{Processors or Restaurants}

Approximately 523,904 food restaurants are officially reported along the country [54,55]. From that amount we asked the two individual sources from the Ministry of Health how many. However, the only response on this subject was that formal restaurants must follow the "Good Hygiene Practices Lecture" equivalent to the NOM-251-SSA1-2009 which is issued along with the legal operation license and must be renew yearly. As there are no official data bases regarding informal street food vendors, we estimated that amount considering an informality rate of $57.2 \%$ reported for the food sector [26].

\subsection{Retailers}

- Supermarkets. Recent reports from the Mexican Chamber of Supermarkets, and Convenience Stores (ANTAD) mentioned the existence of about 55,156 supermarkets and chain stores in the whole country [57]. Traditional markets. Regarding traditional markets, there are 329 for the capital of the country, Mexico City [56]. Given the scarcity of information for the rest of the country, we used these data to estimate a number of markets and street markets across the nation. The markets in Mexico City average one per 27,052 people, we conservatively estimate 1 market for every 27,000 people, or 4153 markets nationwide. Street markets. The same situation happened trying to obtain data regarding the number of street markets or open-air markets. This number was available only for Mexico City (1343); so we used the same method described for estimating a number of street markets, arriving at 16,954 markets nationwide [55,56].

Regarding which markets and street markets follow food standards, we directly asked the main office for traditional markets in Mexico City.

\subsection{Consumers}

For practical purposes, we merged the ten groups (deciles), reported in the official site of INEGI [58] into three categories according their socioeconomic level: $\mathrm{I}-\mathrm{V}=$ low $(60.9 \%)$; VI-VII = medium $(31.9 \%)$; and IX-X = high $(7.2 \%)$.

\section{Results}

3.1. Answers from People Knowledgeable about Certification Processes and Requirements along the Agri-Food Chain

Information from personal interviews confirmed most of the information related to certifications, as well as some opportunities, challenges and scarcities that some agents in the agri-food chain face. This is where we can approach two types of food chain dynamics, according type of REUs, wholesalers, retailers and processors (Table 4). 
Table 4. Answers from eight people interviewed, about certifications processes and requirements along some agents in the agri-food chain.

\section{Answers by Type of Interviewee}

A National Service for Disease Control, Safety and Agri-food Quality (SENASICA) State coordinator. 1. The main federal agencies in charge of food certifications are the Ministry of Agriculture, Cattle, Fisheries, Rural Development and Feeding Affairs (SAGARPA) and SENASICA.

2. There are private and public certifications; in the former we have Primus, SQF, Mexico Good Agricultural Practices (GAP), Mexico Calidad Suprema (MCS) which is half private and non-profit. Federal certifications are mainly on Hazard Analysis Critical Control Point (HACCP) which is considered the most important one and synonymous with safety. Private and public certifications are voluntary and producers adopt them when buyers (domestic or international) ask for them.

3. SENASICA helps certificate REUs in the third phase of that. First producers must ask their local or regional Safety Committee (as is the case of CESAVEP), to make a supervision through a technician; then comes a set of different inspections, and after everything is settled, SENASICA gives the certification.

Private third-party auditor (IL).

1. Their companies trains E3-E6 REUs, with third party auditors "in field and packaging" certifications, because SENASICA has few trainers in the State of Puebla (only from 8 to 10).

2. The general introduction cost 105 USD, and the third-party auditor cost 290 USD, both per person.

3. Requirements are: producers should be organized and legally registered.

4. The difference between the safety efforts from SENASICA and those from the agriculture education, small producers support, Shared Risk Committee (FIRCO), extension and the Marketing and Development Agricultural Markets Agency Services (ASERCA) activities are that the latest are centered in increasing productivity, competitiveness, value added and economic benefits. Nevertheless, they do not adopt certifications because they are costly, and that would increase their food costs; at the same time, it is not required by any agent along the food chain (wholesalers, intermediaries and retailers). Only when some of their buyers (supermarkets or export companies), are interested in their products, do they adopt safety standards.

5. Those hectares certified in the 2018 report of SENASICA-SAGARPA, are from organized producers who have in mind selling their products to supermarkets, exports or specific buyers interested in safety quality and standards. 6. Regarding food standards in wholesalers, traditional and street markets, they are not certified. Those REUs certified use their own means to deliver this food directly to supermarkets, or special restaurants using their own transport (and other infrastructure to keep it safe, as fridges, warehouses, and food techniques); as most of them are organized and share infrastructure, they can avoid those wholesalers, intermediaries and retailers. If some brokers are interested in certified food, they buy their product in their farms, and distribute or export it.

Private third-party auditor (GL).

1. To sell fresh fruits and vegetables food in supermarkets they recommend Primus GFS (an American certification) which is a basic certification, compared to Global Gap and SQF that are more difficult to interpret. 2. The costs for certifications are: 900 USD for field inspections; 450 USD for harvest groups; 1500 USD in packaging. Prices plus taxes and stipends according each inspection needed, before given the final certification. 3. Requirements: first they need a diagnosis through a technician, and a set of three or four sessions before being certified. Additionally, they must have been legally registered.

4. The certification is issued annually, and if all the process and inspections were successful, they give you the certification in 45 days.

Director of the Agronomy School.

1. The main federal agencies in charge of food certifications are SAGARPA and SENASICA.

2. There are private and public certifications; in the former we have Primus, SQF, Mexico GAP, MCS which is half private and a Civil Association. Federal certifications are mainly HACCP which is considered the most important one and synonymous of safety. Private and public certifications are voluntary and producers.

3. Some E4 REUs are certified, but mainly E5 and E6 REUs adopt those standards, when buyers (intermediaries, retailers, domestic or international) ask for and can afford them.

Wholesaler main office/front desk

Efforts to certify wholesalers depend on the municipalities, and state food policies and budgets; the bigger the municipality, the more resources to certify some of their wholesalers' partners; but this is not mandatory.

Traditional markets and street markets' main office $(n=2)$.

Traditional markets and street markets are not certified. It is very difficult to certify all of them as they are too many people involved. 
Table 4. Cont.

Answers by Type of Interviewee
Ministry of Health License Office's.
1. Does not know how many restaurants are certified.
2. The commercial license is issued only once during the restaurant's life, but restaurant owners must assist yearly
to re-new the health seal and attend the NOM-251-SSA1-2009 lecture.
3. Approximately 190 restaurants take the NOM-251-SSA1-2009 lecture weekly ( 9500 yearly, considering only
working weeks).
4. The Ministry of Health does not ask informal restaurants and street vendors to adopt that NOM, because that is
not their duty. Inspections are in three areas (one for food, one for drugs, one for hospitals); for food supervision in
Puebla City (2.5 million people, and 11,843 formal restaurants) they have few inspectors and scarce resources,
and they supervise registered restaurants randomly or due to any complaint. Even if they can take samples from
informal or street food vendors, they cannot punish them because they assume the Ministry of Economy and
Commerce has given them a "permission to operate", or if not, they cannot intervene or punish them.
Additionally, even when they take samples and street food has pathogens, they move to different locations daily,
so they become hard to trace.

Ministry of Health trainer.

The Ministry of Health does not ask informal restaurants and street vendors to adopt the NOM, or report them when they sell contaminated food, because they are only 10 trainers in the whole City of Puebla and it is impossible to reach all street food vendors. If the Ministry of Economy and Commerce has given them "permission to operate" or not, it is that agency's responsibility.

We can summarize those opinions in the following:

- $\quad$ For producers, we can confirm certifications are voluntary, costly and market oriented, this means, they are commercially oriented adopted (mainly when any intermediaries or retailer, national or international, ask for those requirements), not because they worry about their own or other people's health. To meet those standards, it is very important to be organized so they can share resources (water, electricity, warehouses, transport, and legal benefits).

- In the case of wholesalers, intermediaries and retailers, they are not pushed to attend food certifications as the agents before them (REUs), and after them have not adopted any standard as well, so they can freely sell their food without any safety concern; additionally, the number of agents in this part of the chain (near 2.4 million economic units-wholesalers, intermediaries, processors, and retailers), is hard to control.

- In restaurants, we can observe two challenges: a basic disconnection between the Minister of Economy and Commerce, and the Ministry of Health. The former have ignored this part of the legal and formal permits to open and operate a food restaurant; then all efforts from the Minister of Health to control food safety issues are insufficient; additionally, the scarcity of federal budget investment in the Ministry of Health to hire additional inspectors, had led to a hug amount of unsafety food and informal vendor (street food), whom, by the way, do not pay taxes and hence do not contribute in increasing the budget for both Ministries of Economy and Health.

Linking these answers with the secondary data would help us understand each agent's performance and scarcities, and how the whole agri-food chain became two different ones.

\subsection{Certifications in Producers, Products, Type of Certifications and Hectares Achieved in 2018}

Considering the whole amount of REUs and all certifications obtained (including Organic), the number of REUs certified would be of $0.7 \%$ and $148,414.3$ ha $(0.67 \%$ of total available ha utilized for growing crops in the country). These certifications were of three types: $73.1 \%$ in HACCP, $12.2 \%$ in harvested fields; $10.3 \%$ in BUMA, $4.0 \%$ groups of harvest farmers; and $0.4 \%$ in packaging. If we only take into account the E4-E6 REUs certifications, the amount of REUs certified would be around 3.0\%. But assuming that most certifications would be in E5-E6 REUs (as they can afford them), the percent certified would be $8.1 \%$ only in this REUs category (Figure 4 ). Therefore, it is likely that over $99.3 \%$ of REUs would not have any certification (or 97.0\% of E4-E6 and 91.9\% of E5-E6) affecting the fresh 
food sold domestically as well as the respective wholesalers, processors, intermediaries and retailer practices $[28,61,62]$. This is where the division of the agri-food chain starts. Considering the rest of the actors in the agri-food chain, according to this exercise, we would have only $12.5 \%$ of supermarkets and $100 \%$ of established restaurants with some type of certification. Unfortunately, the rest of the actors would not have any documented food safety protocols at best, no implemented food safety protocols at worst.

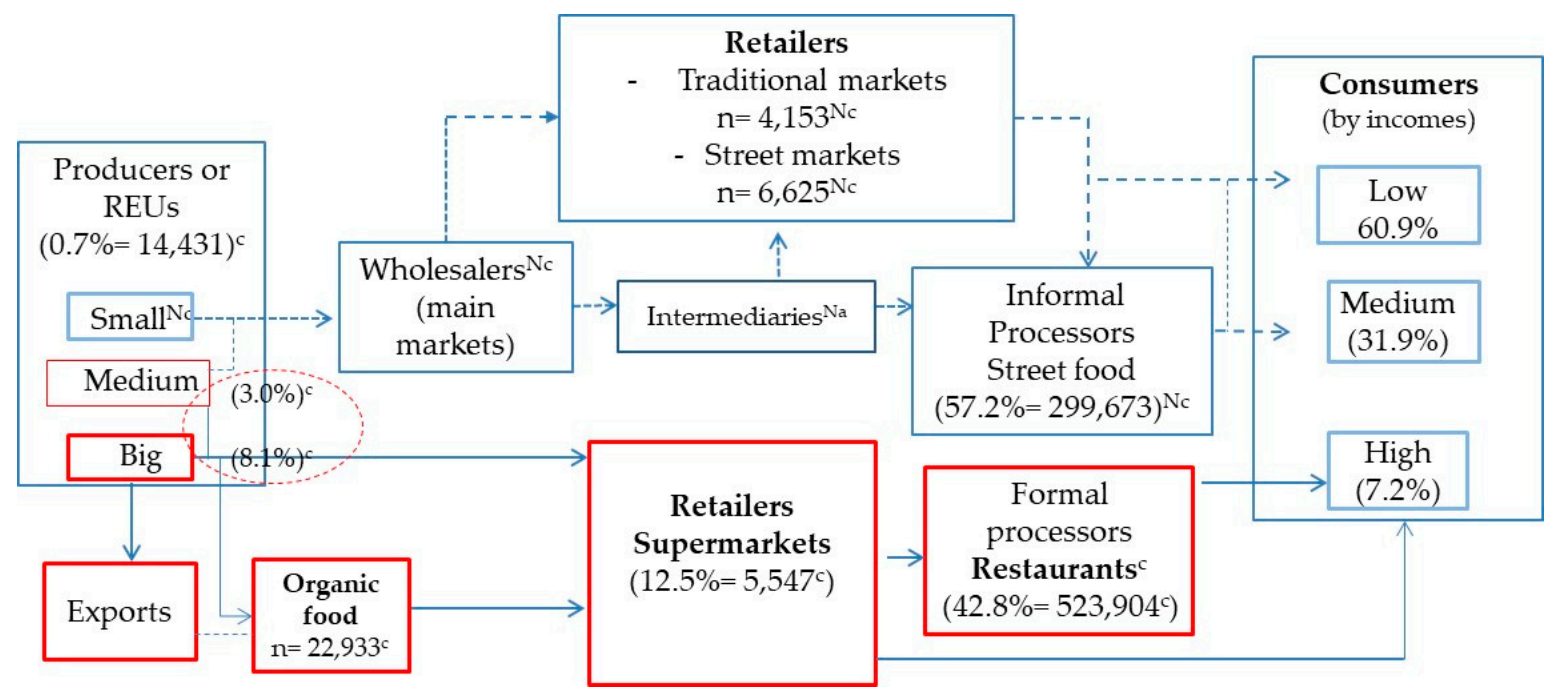

Figure 4. The co-existence of two types of food chain actors, focused on fresh fruits and vegetables and their certification status or not (frequencies and percentages). $\mathrm{Nc}=$ Uncertified food; $\mathrm{C}=$ Certified (highlighted in red). Includes SENASICA-SAGARPA and Organic certifications; $\mathrm{Na}=$ Data not available.

Regarding organic food, the National Council for Organic Production reported 13 certified national organizations (third-party audits) with increased coverage from 600 producers in 2013-2014, to 22,933 in 2017. The number of certified ha were of 142,931; these efforts reached 107 fresh vegetables, and 157 processed products certified as organic [59-61].

According with these data, there are more REUs certified as organic than those in conventional fruits and vegetables reported (22,933 vs. 14,431, respectively); similar amounts of ha certified (148,414 ha in conventional fruits and vegetables vs. 142,931 organic), as well as 125 conventional fruits and vegetables products while there were 107 certified organic products. Due its high standards, they have become very expensive for low-income consumers, that is why they and are considered part of the alternate food chain for high-income market segment and/or exports.

Certifications reported are concentrated on five products (89.1\%), mainly avocado (71.7\%), due its importance in export and large level of production. Avocado obtained the greatest number of certified areas as well, and its production is focused in only four of 32 states in the Western region of the country, where most E5 and E6 REUs are located. For lower-income consumers, avocado is very expensive, the price is about double that of beans (Table 5). In contrast, we analyzed what happened with four food products, considered primary staples of the Mexican diet. Beans and corn tortilla are a fundamental part of Mexico's culinary tradition, with a yearly consumption of 10.2 and $336.6 \mathrm{~kg}$ per capita, respectively. Excluding corn (which reported having only 29 certifications and 577.8 ha certified compared with 10,346 certifications and 4177 hectares for avocado), the rest of the staple foods (beans, rice and wheat), did not report any certifications. Additionally, these four products reported a deficit in their balance of trade that ranged from 0.39 to 72.6 million tons in 2017 (meaning a net import of these staple food products). 
Table 5. Food safety programs for five main exports products (avocado, mango, tomato and chili), compared with four staple food products in Mexico (beans, corn tortilla, rice, wheat-bread), considering the number of certifications, hectares, region as well as their importance in per capita consumption, consumer's price in supermarkets and balance of trade.

\begin{tabular}{|c|c|c|c|c|c|c|c|c|c|}
\hline & Avocado & Mango & Tomato & Lemon & Chili & Beans & $\begin{array}{l}\text { Tortilla } \\
\text { (Corn) }\end{array}$ & Rice & $\begin{array}{l}\text { Wheat (Piece } \\
\text { of Bread) }\end{array}$ \\
\hline $\begin{array}{c}\text { Number of certifications }{ }^{1,2} \\
\text { per product }\end{array}$ & 10,346 & 1182 & 605 & 374 & 345 & None & 29 & None & None \\
\hline $\begin{array}{c}\text { Total of certifications per } \\
\text { product as percentage }{ }^{1}(n=125)\end{array}$ & 71.7 & 8.2 & 4.2 & 2.6 & 2.4 & None & 0.2 & None & None \\
\hline Certified hectares ${ }^{1}$ & 4177.0 & 983 & 279.0 & 192.0 & 259.0 & None & 577.82 & None & None \\
\hline Main production region ${ }^{1,2}$ & West & West & $\begin{array}{l}\text { North and } \\
\text { Center }\end{array}$ & $\begin{array}{l}\text { West and } \\
\text { Southeast }\end{array}$ & $\begin{array}{l}\text { North and } \\
\text { Center }\end{array}$ & $\begin{array}{l}\text { Northwest } \\
\text { and South }\end{array}$ & Center & $\begin{array}{l}\text { West, East and } \\
\text { South }\end{array}$ & $\begin{array}{l}\text { North, West } \\
\text { and Center }\end{array}$ \\
\hline Worldwide exporter place $^{2}$ & 1 & $\mathrm{Na}$ & 1 & 1 & 1 & na & na & na & na \\
\hline Worldwide producer place ${ }^{2}$ & 1 & 4 & 10 & 2 & 2 & 7 & 5 & 59 & 29 \\
\hline $\begin{array}{l}\text { Per capita consumption in } \\
\text { Mexico }^{2}(\mathrm{~kg})\end{array}$ & 8 & 12.4 & 15.2 & 14.5 & 18.1 & 10.2 & 336.6 & 10.3 & 64.0 \\
\hline $\begin{array}{c}\text { Price to consumer in } \\
\text { supermarkets (USD } / \mathrm{kg} \text { ) }\end{array}$ & 3.3 & 1.6 & 1.4 & 1.3 & 1.5 & 1.6 & 0.6 & 1.3 & 0.1 \\
\hline Balance of trade $^{2}$ (million ton) & 5.2 & 042 & 8.3 & 3.8 & 5.5 & -0.39 & -72.6 & -5.7 & -23.1 \\
\hline
\end{tabular}

None $=$ Not reported in such database; na $=$ not available. ${ }^{1}$ Official data per REUs. ${ }^{2}$ SENASICA [59]. ${ }^{3}$ SIAP [60]. ${ }^{4}$ SEDECO [61]. 


\subsection{Economic Barriers for Certification Experienced by Producers}

According the primary information, most food cultivated by small and medium producers (Categories E1-E4) sold in the domestic market, lacked Good Agricultural Practices (GAP), because these practices often require new capabilities (managerial, technical, infrastructure), and are costly. Costs to become certified can be prohibitive to a small entrepreneur, producer, or middleman [62]. Avendaño and Varela [30] and Avendaño et al. [63] found that the certification process increased the total costs by 2 to $10 \%$ for big exporters of fresh vegetable in Northwestern Mexico. These authors estimated that producers faced a total of $\$ 15,000$ USD in production costs during the six to 12 months needed to undergo the full certification process. Information from our two third-party auditors interviewed confirmed that the cost to get Primus GFS (the one needed for access to supermarkets) were \$3306 USD (they need two initial audits, 900 USD each, plus 450 USD for one or two harvest supervisions, another for packaging at 1500 USD, plus 456 USD in taxes and additional expenses for auditors' travel $[39,64]$ (Table 4). Under these constraints, convincing E1-E3 and some E4 producers (whose estimated annual cash income is of 869.1 to 3989.9 USD), to spend their meager resources on food safety certification is highly challenging. Additionally, in the early stages, certification requires investment in infrastructure and technology. Profits decreased and some producers became disappointed which may have led them to drop the certification process, and they are therefore experiencing barriers of entrance to medium- and high-income domestic markets $[30,65]$.

\subsection{Educational and Cultural Barriers}

As Mexican standards and the certification process are mainly used by E5/E6 growers, the process is still complex and worded in highly technical vocabulary and jargon. These standards have been designed by the private sector following international market rules, and some of the information is in English. Their content is difficult to read for E1-E3 and some E4 REUs, who have a limited or no formal education and thus have a limited grasp of the English language. Unless the certification agencies adapt the documents to their educational level by eliminating technical language as some Latin American countries have done, these documents will remain mostly incomprehensible to the majority of producers in Mexico [66-69]. The way certifications are now administered at the national and international level, are exclusive of some REUs, creating a discriminatory and exclusive food policy, for all those agents in the supply chain with fewer resources [70]. The average small producer does not understand what food certifications are or their benefits. A recent exploratory research project applied to 265 participants in the broccoli value chain in Puebla (nine small producers, 14 traditional markets and supermarkets, 15 small restaurants, and 227 medium income consumers), found that $88.9 \%$, $91.1 \%, 68.3 \%$, and $73.1 \%$ respectively, were not aware of any of these certifications [49]. Furthermore, organizational skills are not easy to build in the short run, so the lack of these capabilities delays producers' access to many of these certifications [36]. Another problem is related to the scarcity of official information (from private or public entities), about certification benefits experienced by different type of producers (such as the impact on their productivity, income and employment derived of adopting them), which makes it more difficult to engage in certification ventures [62].

\subsection{Wholesalers and Intermediaries' Certifications}

Information from main office personnel contacted in the main wholesale center in Mexico City (Table 4), confirmed their wholesalers were not certified. We observed how these channels are used to distribute domestic food. This is when "from the farm to the table" efforts became complex [10,71] highlighting that not all food safety issues rely on the production level. In countries like Mexico, there are typically middleman-intermediaries and monopolistic structures in commodity markets that small and medium sized (E2-E4) fresh food producers must contend with to succeed [31,66,72]. In the supply chain, E2-E4 producers are the most vulnerable because they are under pressure to sell their perishable commodities immediately after harvest, as most of these products have not been certified. 
They are often sold to wholesalers and middleman at low prices that do not require food certifications. Middlemen then sell pooled stocks to traditional markets, street markets, low-income supermarkets and informal restaurants, which rarely follow safety protocols or monitoring food safety distribution.

\subsection{Regarding the Number of Retailers (Public and Street Markets) Certified}

We considered the total of 44,377 reported and took those who belong to ANTAD due to the fact that is mandatory to have the Primus GFS to access those supermarkets [38,57]. Considering that amount, there would be approximately 5567 (12.5\%) certified supermarkets. Typically, certified supermarkets serve mostly high-income consumers, sometimes medium-income, which represents $39 \%$ of the Mexican population in urban areas. They do not serve low-income areas $(61 \%$ of the population), or rural ones (20.7 million people), where there is the highest poverty and food insecurity.

\subsection{The Retailers' Importance in Food Safety}

A large proportion of foodborne diseases are caused by food improperly prepared in food establishments including markets, supermarkets, street markets and restaurants $[2,10,72]$. Therefore, as food can be contaminated at any point along the supply chain, food safety issues must be addressed throughout the entire chain. The Mexican Consumers Federal Attendance (PROFECO) [73] reported that $77.6 \%$ of vegetables are still bought in public markets in Mexico City (whose population reaches 20 million people), mainly by medium- (81.3\%) and low-income consumers (77.8\%), compared with high-income ones (69.2\%). This puts more vulnerable consumer's health at risk. Some examples of fresh foods that are purchased by consumers in the lower economic strata [74], have shown that the poorest quality and least desirable varieties of fresh food are most prevalent in places where low income people typically buy food (traditional markets, street markets, cheaper supermarkets and street food).

\subsection{Food Preparation and the Lack of Supervision in Formal and Informal Restaurants}

An official database reported 523,904 restaurants that according to the interviewees from the Ministry of Health (Table 4) hold a legal license, and the lecture of the NOM-251-SSA1-2009 [75]. However, is not in this Ministry's duties to ask informal restaurants and street vendors to adopt that NOM; further more they expressed having few inspectors and scarce resources to inspect them. Even if they can take samples from informal or street food vendors, they cannot punish them because they assume the Minister of Economy and Commerce has given them a "permission to operate", or if not, they cannot intervene. Additionally, even when they take samples and street food have viruses and bacteria, food street vendors move to different locations daily, so they became hard to trace. Due informality rates we estimated there could exist $57.2 \%$ additional restaurants (approximately $299,673)$ lacking any/or safety nor legal permits $[53,54]$. Besides primary information on its web page, they confirmed that street restaurants or street food vendors are not supervised by that Ministry. For this purpose, there is the Federal Commission to Protect Against Safety Risks (COFEPRIS), and it institutes inspections only under three situations: (a) if someone is going to get permission to open or sell food; (b) food vendors, when a person makes a complaint; (c) random inspections [35]. Although COFEPRIS performed 137,356 supervision visits to slaughterhouses, food factories, as well as those producers of food additives, food services, non-alcoholic and alcoholic beverages, purified water, ice, milk and dairy products, fisheries, meat, etc. [76]. Nevertheless, that report does not indicate in which places, municipalities, or states they performed these inspections and supervision actions. If we considered the amount of formal and informal restaurants, retailers, intermediaries and wholesalers (1.6 million economic units), the supervision's scope is at best minimal. Recalling Puebla's interviewees, the Ministry of Health does not have enough personnel to perform supervisions because they are only 10 people working for such issues in the whole city (2.5 million people). Additionally, less than $10 \%$ of the people who get sick in informal restaurants make an official complaint [49]. It is very common to find restaurants without physical proof of the food safety, food hygiene certifications, 
nor governmental inspections [74]. This possibly indicates a basic disconnect between food policies, health and budget to hire enough inspectors, as well as scarce planning strategies between the Ministry of Health, SAGARPA and the Ministry of Economy and Commerce.

\subsection{International Tourism and Food Intake Risks}

Mexico is ranked 6th in tourism visitors worldwide [77]. Since 2007, SAGARPA and the Federal Government established a policy to promote Mexican traditional cuisine at the international level. It is a big challenge having less than $1 \%$ of all restaurants in the country certified in Distintivo " $\mathrm{H}$ " [78,79]. The top countries for international visitors are France (86.9 million); Spain (81.8 million), United States (75.9 million), China (60.7 million), and Italy (58.3 million). Improving certifications is important because people from these countries are generally fairly actively concerned about the safety of their food.

\subsection{Federal Expenditures in Food Safety Issues and Federal Agencies Associated to Safety Issues and Health}

In order to understand if the food safety challenges experienced in Mexico could be explained by insufficient federal resources, we consulted the Mexican budget attributed to those affairs $[25,26,80]$. We found that in 2017, SAGARPA received \$3715.6 million USD which was distributed in several related programs (Figure 5).

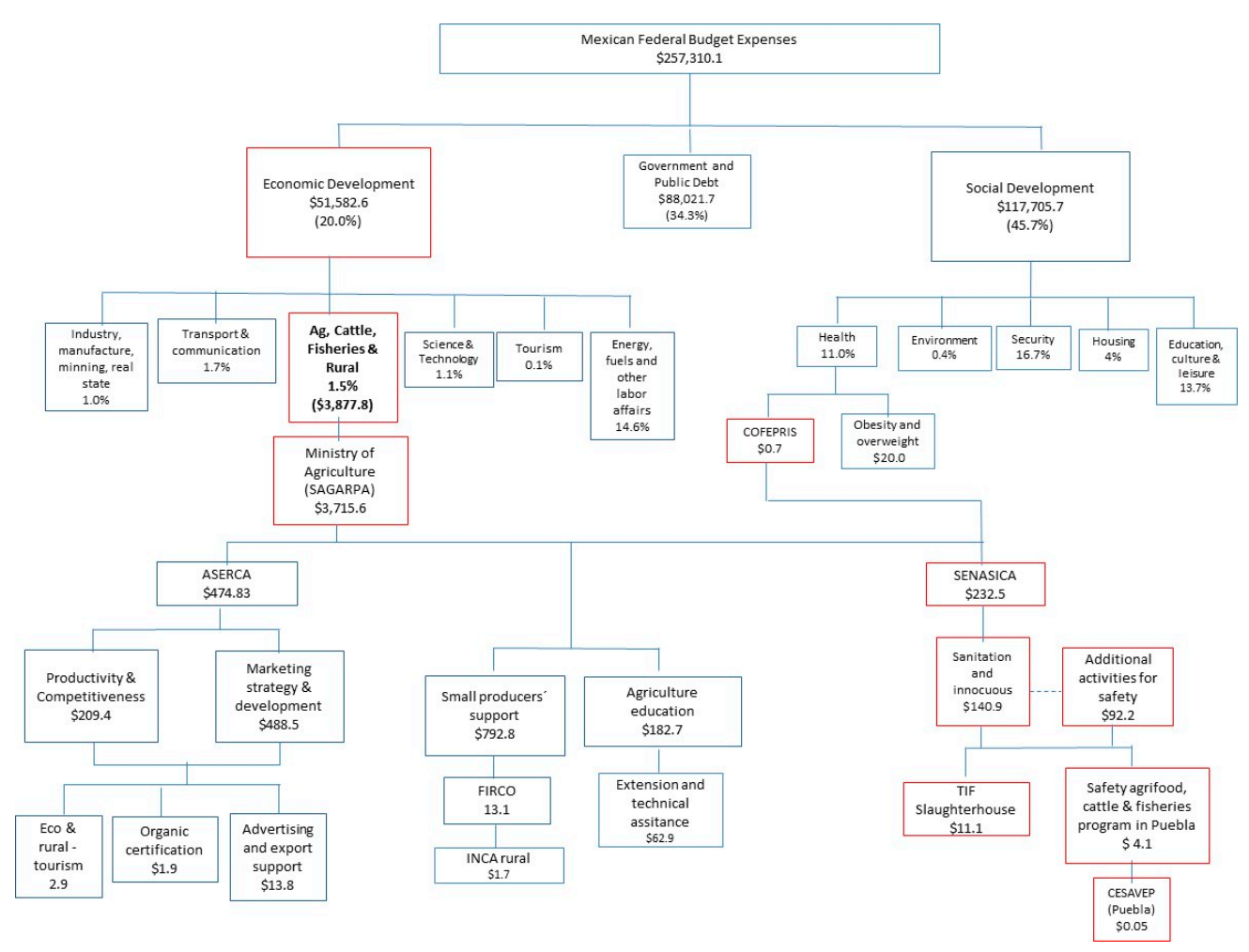

Figure 5. Some public expenditures attending food safety programs in Mexico 2017 (million USD). Acronyms: SAGARPA = Ministry/of Agriculture, Cattle, Fisheries, Rural Development, and Feeding affairs; COFEPRIS = Federal Commission Against Diseases Risks; ASERCA = Marketing and Agricultural Markets Development Services Agency; SENASICA = National Service for Sanitation, Innocuous and Agri-food quality; CESAVEP = State of Puebla Commission for Vegetable Sanitation; SRRC = Reduced Risks and Contaminants System; FIRCO = Shared Risks Escrow; INCA = National Institute to Develop Competences in the Rural Sector Exchange rate: $\$ 1$ USD $=\$ 19.0$ Mexican pesos at the time of writing this article. Highlighted in red are those pertaining to food certifications, or food safety issues, analyzed in this research. Sources: Federal Budget for 2017 [26,80]; SAGARPA, annual reports $(2014 ; 2017)[28,81]$. 
We observed, that in the agricultural sector, there is more than double the amount invested in Marketing Strategy and Development (488.5 million USD), than for SENASICA (232.5 million USD) across the country. Moreover, the amount destined for Advertising, Export Support is higher (13.8 million USD) than that for Puebla's Safety Agrifood Cattle and Fisheries program (4.1 million USD), CESAVEP for Puebla (0.05 million USD) considering Puebla State's importance as a supplier of a large percentage of the nation's vegetables. In the opinion of the auditor interviewed (Table 4), many efforts have been centered on increasing productivity, competitiveness, value added and economic benefits in small producers, including those budgets destined for agriculture education, small producers support, FIRCO, and extension and technical activities (1053.2 million USD). Only when specific buyers (supermarkets or export companies), are interested in specific products with certifications, do REUs institute safety standards. This may be why the SENASICA budget is scarce (although it is not the cause but the consequence of poor policy and governance). We believe "Productivity and Competitiveness", as well as "Marketing Strategy and Development" activities are important for any nation's profits as a whole, but this imbalance in food safety policies undermines inclusive development and equity. This budget allocation leads to the inference that Mexico's priorities are market and externally oriented, and are not shared by all actors who are involved in the domestic food supply chain. Those who operate with scarcity give place to informal networks. Moreover, governmental efforts have considered food safety issues to specific agents in the supply chain and leading them to be supervised by private (sometimes international) third party auditors, which do not meet those food chain agents' budgets and needs.

\section{Discussion}

Throughout this research we discovered that

(a) Unfortunately, Mexican food policies regard food safety issues as focused on the privileged and are oriented to export markets and/or high-income producers-consumers;

(b) This situation has split the agri-food chain in two: one that serves international or high-income consumers, and another that serves domestic markets;

(c) The agri-food chain that serves domestic markets experiences short falls in federal budget expenditures devoted to food safety issues and experiences a lack of coordination in food regulations (transparency, laws, training, supervision, infrastructure), across the various domestic agri-food chain agents. Consequently, this situation has created alternate informal markets which contribute to increase food illnesses due their scarcity of safety practices and oversight. Finally, we observe a vicious circle that mainly affects lower-income peoples' health, wellbeing, and reduces their purchasing power. The process of convalescing and managing the accompanying illnesses could increase their poverty condition or risk of poverty. For these low-income consumers, we also observe large inequities in the food quality and quantity they can access.

These results highlight the importance of enhancing efforts between food policies, governance and the agri-food chain to reach sustainable development, particularly to contribute to four of the sustainable development goals (good health and wellbeing, zero hunger, no poverty, and reduced inequalities). We believe that if only some of the actors in this food chain make serious efforts or have support (technical and financial) to achieve food safety, the rest of the food chain and society will be affected. Not only would imbalances be created or worsened, but this uneven participation could potentially lead to social and economic conflicts (Table 6). 
Table 6. Different implications for people's health according if all, some (or no) actors in the agri-food chain would adopt certifications.

\begin{tabular}{|c|c|c|c|c|c|c|c|}
\hline & \multicolumn{5}{|c|}{ Agents along the Agri-Food Chain } & \multirow[t]{2}{*}{ Results } & \multirow[t]{2}{*}{ Actions } \\
\hline & Producers & Wholesalers & Intermediaries & Retailers & Processors/Restaurants & & \\
\hline $\begin{array}{l}\text { All agents have/know } \\
\text { certifications }\end{array}$ & Yes & Yes & Yes & Yes & Yes & $\begin{array}{l}\text { Food safety, health, well-being. } \\
\text { Economic and social benefits. }\end{array}$ & Enhance to continue. \\
\hline $\begin{array}{l}\text { Some agents have/know } \\
\text { certifications (Mexico's case) }\end{array}$ & $\begin{array}{l}\text { Yes }=0.7 \% \\
\text { No }=99.3 \%\end{array}$ & $\begin{array}{l}\text { Yes Unknown } \\
\text { No, Unknown }\end{array}$ & $\begin{array}{l}\text { Yes Unknown } \\
\text { No, Unknown }\end{array}$ & $\begin{array}{l}\text { Yes }=12.5 \% \\
\text { No }=87.5 \%\end{array}$ & $\begin{array}{l}\text { Yes }=42.8 \% \\
\text { No }=57.2 \%\end{array}$ & \multirow{2}{*}{$\begin{array}{l}\text { Efforts done to improve health } \\
\text { through certifications for few } \\
\text { agents, become in losses for the } \\
\text { whole chain. }\end{array}$} & \multirow{2}{*}{$\begin{array}{l}\text { Increase budget to train and } \\
\text { adopt inspections to specific } \\
\text { actors of the food chain. } \\
\text { Educate the consumer. }\end{array}$} \\
\hline Other possible scenarios & $\begin{array}{l}\text { No } \\
\text { Yes } \\
\text { Yes }\end{array}$ & $\begin{array}{l}\text { Yes } \\
\text { No } \\
\text { Yes }\end{array}$ & $\begin{array}{l}\text { No } \\
\text { Yes } \\
\text { Yes }\end{array}$ & $\begin{array}{l}\text { No } \\
\text { Yes } \\
\text { Yes }\end{array}$ & $\begin{array}{l}\text { Yes } \\
\text { No } \\
\text { Yes }\end{array}$ & & \\
\hline No one have certifications & No & No & No & No & No & $\begin{array}{l}\text { High level of risk in health's people. } \\
\text { Economic and social consequences. }\end{array}$ & $\begin{array}{l}\text { Immediate federal actions } \\
\text { on public policies and } \\
\text { food policies. }\end{array}$ \\
\hline
\end{tabular}


Behind these results there are public policies that historically have affected the agriculture sector and resulted in the present scenario. According to Muñoz-Rodríguez et al. [41], the problem is not only in the amount or scarcity in the federal budgets available, but the way it has been distributed, to whom it had been focused, and under what priorities it has been planned. The fact is that $87 \%$ of public expenses are monetary transfers and private subsidies, that attend political and powerful people's interests, while only $13 \%$ of the budget is distributed among public infrastructure, research, safety and innocuous certifications, training and innovation. Moreover, the main REUs that have benefitted have been big producers compared with medium and low ones (10\% of the bigger REUs concentrate $80 \%$ of subsidies to commercialization issues, $60 \%$ of electricity and water, and $55 \%$ to finance productive assets acquisition [41]). This reasoning coincides with our findings when only five Mexican states concentered $86 \%$ of all food certifications, and those REUs certified are E5-E6. Organic food is another example of public resources given to bigger producers in order to increase their food production the amount of certified REUs in this standard, higher than those for conventional fruits and vegetables; those are hug achievements in only 18 years.

Muñoz-Rodríguez et al. [41] explains again how important is to invest in developing rural areas through an inclusive agricultural development policy. It not only reduces poverty but helps gradually, to attain an industrial development, and through time, it helps to increase the Gross Domestic Product. There are numerous reasons to include those agents across the agri-food chain, that today are excluded form subsidies, financing, training and safety practices: a systemic integration that benefit each one of its participants. Otherwise, the gap between big, medium and small REUs, regions and consumers, would rise three times in 2050, having two different countries: one developed and the other a developing one. The same is now happening in the domestic agri-food chain; we have one very modern, sophisticated, internationally awarded, and we have another food chain that is lagging behind.

Although it is difficult to suggest a solution or a set of solutions, due the complexity of the whole system dynamics and actors involved, we may propose the following, some from similar countries like Mexico, that should be gradually adopted for some agents in the agri-food chain, and are not independent from one another.

\subsection{Certification and Training for Small and Medium Producers: Some Experiences in Some Latin America Countries}

The mere claim that standards exist does not translate immediately into adoption, and not all producers, retailers, processors reach success in the same way and during the same time frame. So, it becomes critical to understand other factors that impact the adoption and following of standards. These are mostly educational, cultural, and organizational $[82,83]$.

- Pérez-Alemán $[69,82]$ worked in Nicaragua, El Salvador and Guatemala "building collective capabilities, learning and standards diffusion", the knowledge behind standards (what and why), and the organizational components to meet them (know-how). The study found out that the process is not an easy issue as it includes tacit to explicit knowledge-sharing, communication and confidence, combining and creating new local knowledge, or mixing local knowledge with national or international knowledge. Shared and spread, this becomes a collective learning process that must be planned, supervised, adjusted and coordinated on a daily basis and must be recorded so that the valuable traditional knowledge can be passed on. Looking at certification from a different perspective $[69,82,83]$, researchers suggest avoiding "taking norms for granted" and "one size fits all", or worrying about why they do not spread the way "they should" in marginalized regions. Pérez-Alemán and Henson and Jaffee [82-84] highlight the importance of using traditional rural and small producers' knowledge, and put it in practice, beyond the mere acquisition of technology, to a transfer of information in a simplified way. Their methodology focuses on developing new competencies to merge old and new processes, products, organizational activities, and building social capital. Systems of training through 
associations and groups or regional, national and international network for small countries also worked.

- In the case of Brazil, it took five years for sugarcane producers to adopt certification processes successfully $[68,85]$. Training auditors and authorities on these issues were more valuable than having seminars for producers and passing out folders that contained the rules. Auditors must adopt a counselor role rather than acting as mere supervisor or police. Big exporters require a different language and support than domestic small and medium producers, intermediaries, processors; they expect a different language because they have different interests along the chain than retailers. Third-party auditors, who in rural areas must be close to the producers, must not act as authorities but should help producers translate what the standards and technical language mean. The third-party auditors can thus become strategic partners to help producers move to change, to make them feel included and that they are participating in a fair game (no winner or losers). The auditors can also try to build a constructive environment and emphasize the role of the cooperative as a community with shared values.

- The increasing demand (internal and external) in Peru for quality asparagus led them to a strong cooperation between private and government sectors, in both standards, and cooperation with investments and infrastructure. This increased income and employment across the supply chain including in cultivation of fresh asparagus, as well as in secondary industries (frozen and canned). In addition, they utilized second-grade produce that did not meet standards for exports, for self-consumption and for low-income markets, thus reducing waste and leading to more employment for some of Peru's poorest people [82]; they would need people to package, transport, distribute and commercialize the product.

Small producers in low- and medium-income countries can develop and discover their strengths and overcome their weaknesses by adopting a proactive strategic response to food safety standards [82]. They can take advantage of their traditional knowledge by discovering new markets or can participate in the creation of new markets or negotiate standards (voice and proactivity) [32,67,85]. In Argentina and the Dominican Republic, it was found that the Codex Standard has little influence in these countries, so they designed their own local, regional and Mercosur rules, trying to avoid entrance barriers to international markets, and re-structured them as a response.

\subsection{Retailer Challenges}

Along the agricultural food chain, certification processes need different strategies, depending on specific characteristics [68,85]. For example, retail (supermarkets), traditional markets and street markets generate different information and require differentiated legislation. While not ideal, this may also include a differentiation between low-medium and high-income consumer markets.

\subsection{Processors and Restaurants Inspections}

COFEPRIS and the Ministry of Health must assume this responsibility and integrate efforts with other institutions such as SAGARPA, as well as the Ministry of Economy to remodel food and health policies. It is important to put a ban and penalize informal street food sellers, who do not adhere to any formalized or monitored safety practice. This, in the medium and long run, would eradicate the culture of working outside of the law, and at the same time could become a medium to gain additional taxes, to be invested in federal domestic certifications (infrastructure, technologies, training, inspectors' wages, among others).

\subsection{Educating the Consumer to Inform about Food Safety at Home}

The change in the actual food policies can take a long time. In the short run, more resources could be invested in order to increase consumer awareness through strategies such as advertising and communication on television, radio, social media, and websites. This communication strategy 
would aim to provide information regarding basic rules people can adopt to improve food safety practices at home. Authorities must improve their administrative procedures to persuade the people to complain when they get sick, as well as when some retailers and processors sell contaminated food. Such institutional mechanisms should be efficient and give a fast response, in order to reduce the spread of diseases.

\section{Conclusions}

As exploratory research, we presented a broader perspective of food certifications, focused on the fruit and vegetable sector and specific agents in the agri-food chain for which we could obtain official data and reports. We did not include: genetically modified foods (exported or imported), pest or water certifications, cattle and fisheries. Sanitation data were not a subject of this study. The lack of official databases and/or the contradictions between those that do exist, led to many estimates, which we have indicated at each occurrence.

In Mexico the federal, regional, and state food safety regulations are fragmented and complicated. In order to inform all food chain agents rapidly and accurately on the status of inspections, control and findings, federal, regional and local inspectors must adopt basic technologies, high levels of transparency and make public those findings in order to give them attention. Hence, it would be necessary to adopt a more integrated inspection system with authorities closely collaborating, sharing updated information, and reforming the legislation and inspections of the entire food supply chain, merging the activities and responsibilities of supervision between the Ministry of Health and the Ministry of Agriculture [4]. Fragmentation and imbalances in the federal budgets have led to all institutions involved being reactive and solving food safety problems after they occur, especially in those unattended vulnerable segments of the chain, instead of acting to prevent these problems arising.

The concentration of these efforts on the high-end and export producers has been documented and shown in this work. This concentration of regulatory, governance, and oversight in this narrow segment of the food chain has led to the bifurcation of the chain into one that produces foods that are qualified at the very top levels of global expectations and certifications, and one that provides nearly no safety, governance, or oversight to the most vulnerable populations.

Primary responsibility on food safety issues is not limited to food producers, preparers, and sellers.

The claim that "food safety begins on the farm" or "from farm to fork" [86] will sound naive if we do not consider the heterogeneity that prevails in the supply chain in developing countries. There is a need to analyze each actor in the food supply chain from a systemic perspective. The analysis must cover each actor's needs, resources, infrastructure, access to credit, educational and cultural profiles. Progress regarding food safety policies continues centered on export issues in many countries like Mexico, which have the pressure of public debt, insecurity, poverty, and where the federal budgets are distributed observing inequities, ignoring their population basic food needs and well-being, some of the United Nations Sustainable Development Goals [87].

The Mexican Ministry of Health and the Ministry of Economy and Commerce, as holders of the public trust along with all government agencies, are significant actors in the wellbeing of society. These public actors must show leadership and play a more engaged and strategic role to promote food safety throughout supply chains $[10,50,72]$.

Unsafe, unhealthy, unregulated, unmonitored food poses a high risk to anyone. If that high risk is concentrated in the most vulnerable members of the population due to economic pressures and realities, sustainable development is a non-starter. When we endanger the vulnerable, especially along health-related issues, we are impacting the general wellbeing of that group. Poor health and wellbeing are a direct threat to jobs and financial stability, which is a detriment to equality and the elimination of poverty. 
Mexico has done an incredible job of producing world-class food with safety and certifications that are the rival of any around the world. The capabilities very evidently exist to perform at that high level nationally. While it is understandable that some things may always remain a "premium" market, it is a continuing tragedy that these good practices, policies, governance, and financing do not serve the vast majority of the population in Mexico.

There is much more work to be done to improve the databases and reduce the number of estimates needed to make analyses such as the one presented for this paper. However, we believe that the work presented here is a cornerstone of that continuing and evolving conversation. To begin laying out strategies to improve our sustainable development outlook, we must first have a framework for understanding where we have been, what our current situation is, and what we must begin to do in order to move in a better direction.

Author Contributions: Y.M.-M., conceived the idea and methods; and J.M.L.O. contributed writing and editing the paper in English.

Funding: This research received no external funding.

Acknowledgments: We thank the Fulbright-García Robles Commission; Jennie Sheerin Popp, Ph.D. Department of Agricultural Economics and Agribusiness, University of Arkansas, and Philip Crandall, Ph.D. Department of Food Science, University of Arkansas.

Conflicts of Interest: The authors declare no conflict of interest. The funders had no role in the design of the study; in the collection, analyses, or interpretation of data; in the writing of the manuscript, or in the decision to publish the results.

\section{References}

1. Food and Agriculture Organization of the United Nations. Food Security. 2006. Available online: http: / / www.fao.org/forestry/13128-0e6f36f27e0091055bec28ebe830f46b3.pdf (accessed on 30 January 2018).

2. World Health Organization. WHO Estimates of the Global Burden of Foodborne Diseases. Foodborne Disease Burden Epidemiology Reference Group 2007-2015. 2015. Available online: http:/ / apps.who.int/iri s/bitstream/10665/199350/1/9789241565165_eng.pdf (accessed on 17 February 2016).

3. Gordana, R. Study of Food Safety Inspections. World Bank, 2009. Available online: http://docu ments.worldbank.org/curated/en/614141468325282214/Study-of-food-safety-inspections (accessed on 23 September 2018).

4. Chandrasekaran, N.; Raghuram, G. Agribusiness Supply Chain Management; CRC Press. Taylor \& Francis Group: Boca Raton, FL, USA, 2014; p. 670, ISBN 978-1-4665-1674-8.

5. Pan American Health Organization. Health in the Americas: 2012 Edition. Regional Outlook and Country Profiles. Scientific and Technical Publication No. 636. World Health Organization Regional Office for the Americas, 2012. Available online: http:/ / www1.paho.org/saludenlasamericas/docs/hia-2012-summary.p df (accessed on 17 February 2016).

6. Batz, M.B.; Henke, E.; Kowalcyk, B. Long-term consequences of foodborne infections. Infect. Dis. Clin. N. Am. 2013, 27, 599-616. [CrossRef] [PubMed]

7. Official Journal of the Federal Government of Mexico. Programa Nacional México sin Hambre. Gobierno Federal, 2014. Available online: http:/ / dof.gob.mx/nota_detalle.php?codigo=5343098\&fecha=30/04/2014 (accessed on 12 November 2015).

8. Consejo Nacional de Evaluación de la Política de Desarrollo Social. Informe de Evaluación de la Política de Desarrollo Social 2016. 2017. Available online: https://www.coneval.org.mx/Evaluacion/IEPSM/Docume nts/IEPDS_2016.pdf (accessed on 2 May 2018).

9. Food and Agriculture Organization of the United Nations. Regional Overview of Food Insecurity Latin America and the Caribbean. 2015. Available online: http://www.fao.org/3/a-i4636e.pdf (accessed on 29 April 2016).

10. Torres, F. México: Expectativas de su seguridad alimentaria en la fase de economía abierta, In Ciencia, Tecnología e Innovación en el Sistema Agroalimentario de México; Martínez-Carrera, D., Ramírez-Juárez, J., Eds.; Biblioteca Básica de Agricultura: Guadalajara, México, 2016; p. 856, ISBN 978-607-715-314-6. 
11. Cuéllar, J.A. Programa de Seguridad Alimentaria: Experiencias en México y Otros Países. Comisión Económica para América Latina, 2011. Available online: http:/ / repositorio.cepal.org/bitstream/handle/1 1362/26070/LCmexL1035_es.pdf?sequence=1 (accessed on 8April 2015).

12. Food and Agriculture Organization of the United Nations. Food Safety Risk Management. Evidence-Informed Policies and Decisions Considering Multiple Factors. FAO Guidance Materials. 2017. Available online: http:/ / www.fao.org/3/i8240en/I8240EN.pdf (accessed on 2 October 2018).

13. Parra-Inzunza, F.; Ocampo-Fletes, I.; Gutiérrez, A. La Experiencia PESA-FAO en la Región Mixteca Baja Poblana. In Seguridad Alimentaria en Puebla: Importancia, Estrategias y Experiencias; Jiménez, F.A., Ed.; Colegio de Postgraduados, Secretaría de Desarrollo Rural del Gobierno del Estado de Puebla, Altres Costa, AMIC: Mexico City, Mexico, 2008; p. 283, ISBN 978-968-839-539-4.

14. Instituto Nacional de Estadística y Geografía. Estadísticas de Mortalidad. 2013. Available online: http:/ / ww w3.inegi.org. $\mathrm{mx} /$ sistemas / sisept/Default.aspx?t=mdemo107\&s=est\&c=23587 (accessed on 4 September 2015).

15. Instituto Nacional de Salud Pública. Encuesta Nacional de Salud y Nutrición. Resultados Nacionales 2012. Instituto Nacional de Salud Pública, 2012. Available online: https:/ / ensanut.insp.mx/informes/ENSANUT 2012ResultadosNacionales.pdf (accessed on 8 October 2018).

16. Diaz-Cayeros, A.; Egan, A.; Floca, M.; Furszyfer, J.; Gell-Redman, M.; Gomez Morin, L.; Razu, Z. Atlas of Epidemiological Transition in Mexico. Center for U.S.-Mexican Studies, 2017. Available online: http: / / usmex-health.ucsd.edu/ (accessed on 13 February 2018).

17. Instituto Nacional de Estadística y Geografía. Anuario Estadístico y Geográfico de los Estados Unidos Mexicanos. 2014. Available online: http:/ / www.beta.inegi.org.mx/app/biblioteca/ficha.html?upc=7028 25097912 (accessed on 14 August 2018).

18. World Health Organization. World Health Day 2015 Food Safety. How Safe Is Your Food? From Farm to Plate, Make Food Safe. Campaign Tool Kit. 2015. Available online: http:/ / www.who.int/campaigns/worldhealth-day /2015/campaign-toolkit.pdf?ua=1 (accessed on 2 October 2018).

19. World Health Organization. Food Safety Key Facts. Fact Sheet No. 399. 2015. Available online: http: / / www.who.int/campaigns/world-health-day/2015/fact-sheet.pdf?ua=1 (accessed on 26 September 2018).

20. Instituto Nacional de Estadística y Geografía. Sistema de Cuentas Nacionales de México. Cuentas de Bienes y Servicios 2014. 2015. Available online: http:/ / www.inegi.org.mx/saladeprensa/boletines/2015/especiale s/especiales2015_09_3.pdf (accessed on 8 October 2018).

21. Official Journal of the Federal Government of Mexico. Decreto por el que se Aprueba el Programa Sectorial de Desarrollo Agropecuario, Pesquero y Alimentario 2013-2018. Cuarta Sección. 13 de Diciembre. Secretaría de Agricultura, Ganadería, Desarrollo Rural, Pesca y Alimentación. 2013. Available online: http:/ / dof.gob. $\mathrm{mx} /$ nota_detalle.php?codigo=5326583\&fecha=13/12/2013 (accessed on 12 November 2015).

22. Jiménez, F.A. Seguridad Alimentaria en Puebla: Importancia, Estrategias y Experiencias; Colegio de Postgraduados, Secretaría de Desarrollo Rural del Gobierno del Estado de Puebla, Altres Costa, AMIC: Texcoco, Mexico, 2008; p. 283, ISBN 978-968-839-539-4.

23. Comisión para la Sanidad Vegetal del Estado de Puebla. Situación Actual del Programa. 2017. Available online: http:/ / www.cesavep.org/campanias/Pia/pia_sit_act.html (accessed on 23 April 2017).

24. Comisión para la Sanidad Vegetal del Estado de Puebla. 2015. Available online: https://www.gob.mx/sen asica/acciones-y-programas/acciones-estrategicas-de-sanidad-vegetal (accessed on 23 April 2017).

25. Official Journal of the Federal Government of Mexico. Federal Expenses Budget Approved for 2015. 2014. Available online: http:/ / www.dof.gob.mx/nota_detalle.php?codigo=5374053\&fecha=03/12/2014 (accessed on 12 November 2015).

26. Secretaría de Hacienda y Crédito Público. Presupuesto de Egresos de la Federación 2017. Versión Ciudadana. Secretaría de Hacienda y Crédito Público, 2017. Available online: http:/ / www.secretariadoejecutivo.gob.mx/docs/pdfs/normateca/Presupuestos/Presupuesto\%20 de $\% 20$ Egresos $\% 20$ de $\% 201$ a $\% 20$ Federaci $\%$ C3\%B3n $\% 20$ para $\% 20$ el $\% 20$ Ejercicio $\% 20 F i s c a l \% 202017 . p d f$ (accessed on 15 January 2018).

27. Villa, M. ¿Qué hacemos con el campo? 2nd ed.; Mundi-Prensa: Texcoco, México, 2011; p. 433, ISBN 9786077533696. 
28. Secretaría de Agricultura, Ganadería, Desarrollo Rural, Pesca y Alimentación. 5th SAGARPA Activities Report (2016-2017). 2017. Available online: https://www.gob.mx/cms/uploads/attachment/file/255710/5 TO_INFORME_2017_web.pdf (accessed on 20 January 2017).

29. Secretaría de Economía. Estadísticas de Comercio Exterior de México. Subsecretaría de Comercio Exterior. Total Exportaciones e Importaciones. 2016. Available online: http:/ /www.gob.mx/cms/uploads/attachmen t/file/81863/Acum-Exporta.pdf (accessed on 11 March 2016).

30. Avendaño, B.; Varela, R. La adopción de estándares en el sector hortícola de Baja California. Estudios Fronterizos 2010, 11, 171-202.

31. Salles de Almeida, J. “Normas privadas": El nuevo desafío para las exportaciones de los países en desarrollo. Comisión Económica para América Latina, Naciones Unidas. 2008. Available online: http:/ / repositorio.ce pal.org/bitstream/handle/11362/4430/S0800046_es.pdf?sequence=1 (accessed on 23 November 2015).

32. The Codex Alimentarius. Available online: http://www.fao.org/fao-who-codexalimentarius/about-codex/ en/\#c453333 (accessed on 19 November 2017).

33. Food Safety Modernization Act. 2017. Available online: https://www.gob.mx/sagarpa/prensa/capacitaci on-en-ley-de-inocuidad-de-estados-unidos-beneficiara-a-productores-mexicanos (accessed on 23 January 2017).

34. Secretaría de Economía. Catálogo Mexicano de Normas. 2018. Available online: https:/ /www.sinec.gob.mx /SINEC/ (accessed on 8 October 2018).

35. Comisión Federal para la Protección Contra Riesgos Sanitarios. Proceso de Vigilancia Sanitaria. Comisión de Operación Sanitaria, 2018. Available online: https:/ /www.gob.mx/cofepris/acciones-y-programas/proceso -de-de-vigilancia-sanitaria-75408 (accessed on 8 October 2018).

36. Consejo Nacional de Evaluación de la Política de Desarrollo Social. Instrumentación de Acciones para mejorar las Sanidades a través de Inspecciones Fitozoosanitarias. Informe de la Evaluación Específica de Desempeño 2012-2013. 2014. Available online: http:/ / www.coneval.org.mx/Informes/Evaluacion/Especif icas_Desempeno2012/SAGARPA/8_U002/8_U002_Completo.pdf (accessed on 10 November 2015).

37. México Calidad Suprema. México Calidad Suprema, el Sello de los Mexicanos. 2018. Available online: http:/ / www.mexicocalidadsuprema.org/proyectos / (accessed on 15 October 2018).

38. Globalstd.com. (Private third-party auditors). Personal communication, 2018.

39. Walmart. Requerimientos de Seguridad Alimentaria para Proveedores de Alimentos Procesados y Productos Agrícolas. 2018. Available online: https:/ / cdn.corporate.walmart.com/b3/f4/3b20e09f44868655259e8bb5 70fe/manual-seguridad-alimentos-procesados-agricolas.pdf (accessed on 14 February 2018).

40. Ramírez-Juárez, J. La agricultura familiar y su contribución a la seguridad alimentaria: Límites y posibilidades. In Ciencia, Tecnología e Innovación en el Sistema Agroalimentario de México; Martínez-Carrera, D., Ramírez- Juárez, J., Eds.; Biblioteca Básica de Agricultura: Guadalajara, México, 2016; p. 856, ISBN 978-607-715-314-6.

41. Muñoz-Rodríguez, M.; Santoyo-Cortés, V.H.; Gómez-Pérez, D.; y Altamirano-Cárdenas, J.R. Otro campo es possible. In Agenda Pública y Política con Relación al Campo Mexicano; Universidad Autónoma Chapingo: Texcoco, México, 2018; p. 121.

42. Consejo Nacional de Evaluación de la Política de Desarrollo Social en México 2012. 2012. Available online: https:/ / www.coneval.org.mx/informes/evaluacion/iepds2012/pages-iepdsmex2012-12nov-vfin al_lowres6.pdf (accessed on 14 October 2018).

43. Instituto Nacional de Estadística y Geografía (INEGI). Encuesta Nacional de Ocupación y Empleo. Tasa de Informalidad Laboral. Indicadores Estratégicos. Primer Trimestre. 2018. Available online: http:/ /www.beta .inegi.org.mx/app/buscador/default.html?q=tasa+de+informalidad\#tabMCcollapse-Indicadores (accessed on 9 August 2018).

44. United States Department of Agriculture. Economic Research Service. Budget Shares for Broad Aggregates and Conditional Budget Shares for Food Categories 2005. Available online: http:/ / ers.usda.gov/data-prod ucts/international-food-consumption-patterns.aspx\#26207 (accessed on 3 October 2015).

45. Case, K.E.; Fair, R.C. Principios de Microeconomía, 4th ed.; Prentice Hall: Mexico City, México, 1995; p. 620, ISBN 0-13-440918-3. 
46. Organisation for Economic Co-Operation and Development. Health at a Glance 2017: OECD Indicators; OECD Publishing: Paris, France, 2017. Available online: https:/ /www.health.gov.il/publicationsfiles/healthatagl ance2017.pdf (accessed on 26 September 2018).

47. Secretaría de Salud. Estrategia Nacional para la Prevención y el Control del Sobrepeso, la Obesidad y la Diabetes. 2013. Available online: https://www.gob.mx/cms/uploads/attachment/file/348803/Estrategi a_con_portada.pdf (accessed on 20 January 2018).

48. Hoffmann, S.; Anekwe, T.D. Making Sense of Recent Cost-of-Foodborne-Illness Estimates. United States Department of Agriculture, 2013. Available online: https:/ / www.ers.usda.gov / webdocs/publications / 4379 6/40344_eib118.pdf?v=0 (accessed on 2 October 2018).

49. Mayett- Moreno, Y.; Sabogal-Salamanca, M.; Popp, J.S.; Crandall, P.; Arvizu-Barrón, E. Is Food Safety a Real Concern in Mexico and Colombia? A Preliminary Report among Small Producers, Retailers and Consumers. Dev. Policy Rev. 2017, 36, O880-O896. [CrossRef]

50. Kuchler, F. How Much Does It Matter How Sick You Get? Consumers' Responses to Foodborne Disease Outbreaks of Different Severities. 2015. Available online: https:/ /www.ers.usda.gov/webdocs/publication s/45419/53640_err193.pdf?v=42243 (accessed on 2 October 2018).

51. Hernández, R.; Fernández- Collado, C.; Baptista, P. Metodología de la investigación, 6th ed.; Mc Graw Hill: Mexico City, México, 2014; p. 632, ISBN 978-1456223960.

52. Central de Abasto de la Ciudad de México. Available online: https://uneabasto.com/informacion-de-centr al-de-abastos.htm (accessed on 8 September 2018).

53. Sistema Nacional de Información e Integración de Mercados. Secretaría de Economía. Available online: http:/ / www.economia-sniim.gob.mx/nuevo/ (accessed on 26 September 2018).

54. Instituto Nacional de Estadística y Geografía. Directorio Estadístico Nacional de Unidades Económicas. 2018. Available online: http:/ / www.beta.inegi.org.mx/app/mapa/denue/ (accessed on 26 September 2018).

55. Instituto Nacional de Estadística y Geografía. Censos Económicos 2014. La Industria Restaurantera en México. 2016. Available online: http:/ / www.beta.inegi.org.mx/app/biblioteca/ficha.html?upc=70282508 0334 (accessed on 28 September 2018).

56. Secretaría de Desarrollo Económico. Ciudad de México. Listado de Mercados Públicos. 2015. Available online: http:/ / www.sedecodf.gob.mx/archivos/Menu_Horizontal/2015/InformacionRelevante/Listado _de_Mercados_Publicos.pdf (accessed on 28 September 2018).

57. Asociación Nacional de Tiendas de Autoservicio y Departamentales. 2018. Available online: https://antad. net/ (accessed on 12 October 2018).

58. Instituto Nacional de Estadística y Geografía. Encuesta Nacional de Ingresos y Gastos de los Hogares. 2010. Available online: http:/ / www3.inegi.org.mx/rnm/index.php/catalog/36 (accessed on 4 September 2015).

59. Servicio Nacional de Sanidad, Inocuidad y Calidad Agroalimentaria (SENASICA). Directorio de Empresas y áreas Reconocidas 08/10/2018. Available online: https:/ /www.gob.mx/cms/uploads/attachment/file/40 5446/DIRECTORIO_EMPRESAS_Y_AREAS_al_17_de_octubre_2018.pdf (accessed on 15 October 2018).

60. Atlas Agroalimentario. Servicio de Información Agroalimentaria y Pesquera (SIAP). 2018. Available online: https:/ /nube.siap.gob.mx/gobmx_publicaciones_siap/pag/2018/Atlas-Agroalimentario-2018 (accessed on 12 October 2018).

61. Ciudad de México CDMX-SEDECO. Cuadro Comparativo de Precios de Productos Básicos Correspondientes a la 2da y 3era Semana de Octubre. 2018. Available online: https://www.sedeco.cdmx.gob.mx/storage/app /media/Canasta\%20Basica/Seguimiento\%20Diario/2018/Octubre/Comparativo\%20tercera\%20semana \%20de\%20octubre\%202018.pdf (accessed on 24 October 2018).

62. Lee, J.; Gereffi, G.; Beauvais, J. Global value chains and agrifood standards: Challenges and possibilities for smallholders in developing countries. Proc. Natl. Acad. Sci. USA 2012, 109, 12326-12331. [CrossRef] [PubMed]

63. Avendaño, B.; Schwentesius, R.; Lugo, S. El impacto de la Iniciativa de Inocuidad Alimentaria de Estados Unidos en las Exportaciones de Hortalizas Frescas del Noroeste de México. Región y Sociedad, 2006. Available online: http:/ / www.redalyc.org/articulo.oa?id=10203601 (accessed on 3 November 2015).

64. IPAAGRO-LUUM. (Private third-party auditors). Personal communication, 2018.

65. Herbert, M.; Mora, J.S.; Martínez, M.A.; García-Mata, R. Impacto económico de la Ley Federal de Sanidad Vegetal en el Mercado Mexicano de Limón Persa. Revista Mexicana de Ciencias Agrícolas 2010, 1, 321-333. 
66. Arvizu, E.; Mayett-Moreno, Y.; Martínez-Flores, J.L.; Olivares-Benítez, E.; Flores-Miranda, L. Análisis de producción y comercialización hortícola del Estado de Puebla: Un enfoque de cadena de valor. Revista Mexicana de Ciencias Agrícolas 2015, 6, 779-792. [CrossRef]

67. Neal, J.A.; O’Bryan, C.A.; Crandall, P.G. Preventing Post-Processing Contamination in a Food Nugget Processing Line When Language Barriers Exist. Agric. Food Anal. Bacteriol. 2014, 4, 20-26.

68. Coslovsky, S. Enforcing Food Quality and Safety Standards in Brazil: The Case of COBRACANA. Ann. Am. Acad. Political Soc. Sci. 2013, 649, 122-138. [CrossRef]

69. Pérez- Alemán, P. Global standards and local knowledge building: Upgrading small producers in developing countries. Proc. Natl. Acad. Sci. USA 2012, 109, 12344-12349. [CrossRef] [PubMed]

70. Post, D.L. Standards and Regulatory Capitalism: The diffusion of Food Safety Standards in Developing Countries. Ann. Am. Acad. Political Soc. Sci. 2005, 598, 168-183. [CrossRef]

71. Food and Agriculture Organization of the United Nations. Food Chain Crisis Early Warning Bulletin. 2018. Available online: http:/ / faostat.fao.org/site/339/default.aspx (accessed on 29 August 2018).

72. Lugo-Morín, D.R.; Ramírez-Juárez, J.; Méndez-Espinoza, J.A.; Peña-Olvera, B. Asymmetric social networks in the horticultural system in the Tepeaca Valley, Mexico. Economía Sociedad y Territorio 2010, 10, 207-230.

73. Procuraduría Federal del Consumidor. Survey Regards Places Where Households Buy Their Groceries. 2014. Available online: http:/ / www.profeco.gob.mx/encuesta/mirador/2014/Encuesta_sobre_lugares_de_com pra.pdf (accessed on 5 December 2014).

74. Mayett, Y.; Martínez-Carrera, M. Estrategias para promover el consumo de hongos comestibles en México, con base en sus propiedades funcionales y medicinales. In Ciencia, Tecnología e Innovación en el Sistema Agroalimentario de México; Martínez-Carrera, D., Ramírez- Juárez, J., Eds.; Biblioteca Básica de Agricultura: Guadalajara, México, 2016; p. 856, ISBN 978-607-715-314-6.

75. Norma Oficial Mexicana NOM-251-SSA1-2009. Gobierno Federal. Available online: http://dof.gob.mx/not a_detalle.php?codigo $=5133449 \&$ fecha $=01 / 03 / 2010$ (accessed on 20 January 2018).

76. Secretaria de Salud. 5to. Informe de Labores 2016-2017. Gobierno Federal, 2017. Available online: https: //www.gob.mx/cms/uploads/attachment/file/254434/5to_IL_SS.pdf (accessed on 20 January 2018).

77. Secretaría de Turismo. México, Sexto Lugar del Ranking Mundial en Arribo de Turistas Internacionales, confirma OMT. 2018. Available online: https:/ / www.gob.mx/sectur/prensa/mexico-sexto-lugar-del-rank ing-mundial-en-arribo-de-turistas-internacionales-confirma-omt (accessed on 30 August, 2018).

78. Secretaría de Turismo. Distintivo H. Available online: http:/ /www.sectur.gob.mx/gobmx/tramites-y-servi cios / certificacion-turistica/distintivo-h/ (accessed on 12 October 2018).

79. Secretaría de Agricultura, Ganadería, Desarrollo Rural, Pesca y Alimentación; Secretaría de Desarrollo Social; Instituto Nacional de Salud Pública; Food and Agriculture Organization of the United Nations. Panorama de la Seguridad Alimentaria y Nutricional en México. 2012. Available online: http:/ /www.colpos.mx/wb_p df/Panorama_Seguridad_Alimentaria.pdf (accessed on 12 April 2015).

80. Secretaría de Hacienda y Crédito Público. Presupuesto de Egresos de la Federación 2015. Versión Ciudadana. Secretaría de Hacienda y Crédito Público, 2015. Available online: http:/ /www.transparenciapresupues taria.gob.mx/work/models/PTP/Home/Ultimas_Publicaciones/PEF_ciudadano_2015.pdf (accessed on 12 November 2015).

81. Secretaría de Agricultura, Ganadería, Desarrollo Rural, Pesca y Alimentación. 2nd SAGARPA Activities Report (2013-2014). 2014. Available online: http:/ /www.sagarpa.gob.mx/Transparencia/Informes/SEGU NDO_INFORME_DE_LABORES_2013_\%202014_SAGARPA.pdf (accessed on 16 November 2015).

82. Pérez- Alemán, P. Collective Learning in global diffusion: Spreading quality standards in a developing country cluster. Organ. Sci. 2011, 22, 173-189. [CrossRef]

83. Henson, S.; Jaffee, S. Standards and Agro-Food Exports from Developing Countries: Rebalancing the Debate. World Bank Policy. Research Working Paper 3348. 2004. Available online: http:/ / elibrary.worldbank.org/d oi/abs/10.1596/1813-9450-3348 (accessed on 13November 2015).

84. Henson, S.; Jaffee, S. Understanding Developing Country Strategic Responses to the Enhancement of Food Safety Standards. World Econ. 2008, 31, 548-568. [CrossRef]

85. Donovan, J.A.; Caswell, J.; Salay, E. The Effect of Stricter Foreign Regulations on Food Safety Levels in Developing Countries: A Study of Brazil. Rev. Agric. Econ. 2001, 23, 163-175. [CrossRef] 
86. Anusuya, E.; Bihn, A.; Gravani, R.B.; Scott, D.L.; Pritts, M.P. Food Safety Begins on the Farm. A Grower's Guide. Good Agricultural Practices for Fruits and Vegetables. Cornell Good Agricultural Practices Program. 2000. Available online: https:/ / ecommons.cornell.edu/handle/1813/2209 (accessed on 8 October 2018).

87. United Nations. Sustainable Development Goals. 17 Goals to Transform Our World. 2016. Available online: https://www.un.org/sustainabledevelopment/sustainable-development-goals/ (accessed on 18 November 2017).

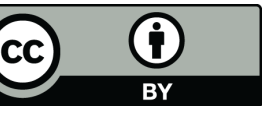

(C) 2018 by the authors. Licensee MDPI, Basel, Switzerland. This article is an open access article distributed under the terms and conditions of the Creative Commons Attribution (CC BY) license (http:/ / creativecommons.org/licenses/by/4.0/). 